3

$5{ }^{1}$ Institute of Volcanology and Seismology, Petropavlovsk-Kamchatsky, Russia

$6 \quad{ }^{2}$ GEOMAR Helmholtz Centre for Ocean Research Kiel, Kiel, Germany

$7 \quad{ }^{3}$ Vernadsky Institute of Geochemistry and Analytical Chemistry, Moscow, Russia

$8{ }^{4}$ Geological Institute, Moscow, Russia

$9{ }^{5}$ School of Geography, Archaeology and Palaeoecology, Queen's University Belfast, Belfast, 10 UK

$11{ }^{6}$ Department of Earth and Environmental Science, New Mexico Institute of Mining and 12 Technology, Socorro, USA

$13 \quad{ }^{7}$ V. I. Il ichev Pacific Oceanological Institute, Vladivostok, Russia

14 Submitted for publication to International Journal of Earth Sciences

15 Corresponding author: Vera Ponomareva

16 E-mail: vera.ponomareva1@gmail.com

17 Tel: +79263856300

18

19

Key words: explosive eruptions; tephra; volcanic glass; chronology; Kamchatka;

21 Shiveluch 
The $\sim 16 \mathrm{ka}$ long record of explosive eruptions from Shiveluch volcano (Kamchatka, NW Pacific) is refined using geochemical fingerprinting of tephra and radiocarbon ages. Volcanic glass from 77 prominent Holocene tephras and four Late Glacial tephra packages was analyzed by electron microprobe. Eruption ages were estimated using 113 radiocarbon dates for proximal tephra sequence. These radiocarbon dates were combined with 76 dates for regional Kamchatka marker tephra layers into a single Bayesian framework taking into account the stratigraphic ordering within and between the sites. As a result, we report $\sim 1700$ high-quality glass analyses from Late Glacial-Holocene Shiveluch eruptions of known ages. These define the magmatic evolution of the volcano and provide a reference for correlations with distal fall deposits. Shiveluch tephras represent two major types of magmas which have been feeding the volcano during the Late Glacial-Holocene time: Baidarny basaltic andesites and Young Shiveluch andesites. Baidarny tephras erupted mostly during the Late Glacial time ( $\sim 16-12.8 \mathrm{ka}$ BP) but persisted into the Holocene as subordinate admixture to the prevailing Young Shiveluch andesitic tephras ( 12.7 ka BP - present). Baidarny basaltic andesite tephras have trachyandesite and trachydacite $\left(\mathrm{SiO}_{2}<71.5\right.$ wt. \%) glasses. The Young Shiveluch andesite tephras have rhyolitic glasses $\left(\mathrm{SiO}_{2}>71.5\right.$ wt. \%). Strongly calc-alkaline medium-K characteristics of Shiveluch volcanic glasses along with moderate $\mathrm{Cl}, \mathrm{CaO}$ and low $\mathrm{P}_{2} \mathrm{O}_{5}$ contents permit reliable discrimination of Shiveluch tephras from the majority of other large Holocene tephras of Kamchatka. The Young Shiveluch glasses exhibit wave-like variations in $\mathrm{SiO}_{2}$ contents through time that may reflect alternating periods of high and low frequency/volume of magma supply to deep magma reservoirs beneath the volcano. The compositional variability of Shiveluch glass allows geochemical fingerprinting of individual Shiveluch tephra layers which along with age estimates facilitates their use as a dating tool in paleovolcanological, paleoseismological, paleoenvironmental, and archaeological studies. Electronic tables accompanying this work offer a tool for statistical correlation of unknown tephras with proximal Shiveluch units taking into account sectors of actual tephra dispersal, eruption size and expected age. Several examples illustrate the effectiveness of the new database. The data are used to assign a few previously enigmatic wide-spread tephras to particular Shiveluch eruptions. Our finding of Shiveluch tephras in sediment cores in the Bering Sea at a distance of $\sim 600 \mathrm{~km}$ from the source permits reassessment of the maximum dispersal distances for Shiveluch tephras and provides links between terrestrial and marine paleoenvironmental records. 
57 Correlations of individual tephra layers using geochemical fingerprinting and dating have been widely used and have applications in volcanology and various fields of paleoenvironmental research (Lowe 2011, and references herein). Tephrochronology permits reconstructing the past explosive activity of a volcano which can then be used for understanding the tectonic and magmatic processes governing the volcanic pulses (e.g., Oladottir et al. 2008). A single tephra layer or a suite of stratigraphically ordered tephra layers can serve as excellent markers which help to correlate and date various depositional successions and ensure direct comparisons between different paleoenvironmental archives (e.g., Davies et al. 2008). Correlations of tephra layers between disparate sites may, however, be complicated if several tephras from the same volcano are close in composition but dispersed in different directions from the volcano. Knowledge of all major tephra layers from a volcano, and their geochemical characteristics, can significantly improve understanding of distal tephrostratigraphy.

Andesitic tephras are considered to be difficult for geochemical identification and correlation for various reasons (e.g., Lowe 2011 and refs herein). Andesitic volcanoes commonly produce numerous and compositionally similar tephras which form complex proximal sequences. These sequences sometimes are partly eroded or only partly exposed (e.g., Donoghue et al. 2007; Turner et al. 2009). In addition, andesitic tephras often are highly vesicular and crystallized, so they may contain only tiny pockets of microlite-free interstitial glass suitable for microprobe analysis. Some microprobe glass analyses therefore might be non-representative because of entrapment of mineral phases. Even if this does not happen, glass may be compositionally heterogeneous due to magma mixing and crystallization, which makes statistical comparisons and correlations of different tephras difficult.

In spite of these problems, studies of proximal pyroclastic sequences of dominantly andesitic volcanoes are necessary for reconstructing the volcano's eruptive history and characterizing all the tephra layers that have the potential to work as marker layers in distal sites. Here we present a record of Late Glacial - Holocene explosive eruptions from the dominantly andesitic Shiveluch volcano (Kamchatka, NW Pacific). We estimate the age of the eruptions based on calibration of a sequence of $113{ }^{14} \mathrm{C}$ dates for proximal pyroclastic deposits and 76 dates for marker tephra layers from other volcanoes obtained elsewhere. We provide a first-order evaluation of compositional changes in the Shiveluch magmas over time based on bulk rock and glass composition in proximal pyroclastic units. Characteristics of glass from dated proximal pyroclastic units allow us to provide a set of analyses that can be used as a reference for distal 
eruptive history (Ponomareva et al. 2007) and provides new insights into temporal variability of its magma compositions.

\section{Shiveluch volcano}

The andesitic Shiveluch volcano is a highly explosive eruptive center with historical (1600-ies present) magma discharge rates of 25-30 Mt/year (Melekestsev et al. 1991), an order of magnitude higher than typical island arc volcanoes (Davidson and DeSilva 2000). Shiveluch is located $\sim 60 \mathrm{~km}$ south of the northern edge of the subducting Pacific Plate and is spatially related to the junction of the Kuril-Kamchatka and Aleutian arcs (Fig. 1; Davaille and Lees 2004; Portnyagin et al. 2007). Written records of Shiveluch activity date back to AD 1739 (Gorshkov and Dubik 1970). The first large explosive eruption examined in detail occurred in 1964. It involved a sector collapse, subsequent phreatic explosion, a plinian eruption resulting in fall and pyroclastic density current deposits with a total bulk volume of $0.6-0.8 \mathrm{~km}^{3}$, and lahars (Gorshkov and Dubik 1970; Belousov 1995). Since 1980 lava domes have been growing in the 1964 crater, occasionally producing block-and-ash and pumice flows, landslides, lahars and minor to moderate ash falls (Dvigalo 1984; Gorelchik et al. 1997; Khubunaya et al. 1995; Zharinov et al. 1995; Fedotov et al. 2004; Zharinov and Demyanchuk 2013). The most recent activity was in 2015 (http://www.kscnet.ru/ivs/kvert/volc.php?name=Sheveluch\&lang=en). The frequent ash plumes from Shiveluch pose hazards to local towns and to dozens of daily air flights between North America and Far East (http://www.kscnet.ru/ivs/kvert/index eng.php).

Since the onset of its activity over $80 \mathrm{ka}$ (Pevzner et al. 2014), Shiveluch has built a composite volcanic edifice rising to over $3200 \mathrm{~m}$ (Fig. 1). The volcano with its debris flow plain occupies an area of $\geq 1300 \mathrm{~km}^{2}$. The edifice consists of the late Pleistocene Old Shiveluch volcano which was destroyed by a collapse crater, and the currently active Young Shiveluch (YSH) eruptive center nested in the latter. The Old Shiveluch core is formed by a $\sim 2000 \mathrm{~m}$ thick pile of coarse massive or weakly stratified pyroclastic deposits, probably enclosing lava domes, which is crowned with a series of lava flows erupted from four vents (Gorbach et al. 2013). The easternmost vent forms the $3283 \mathrm{~m}$ high Main Summit; two western vents (Baidarny vent and Southern vent) and their lava flows form Baidarny Spur (Figs. 1 and 2). Major sector collapse likely occurred in the late Pleistocene, somewhat earlier than the Last Glacial Maximum (Melekestsev et al. 1991). The resulting collapse crater has later been reshaped by numerous avalanches (Ponomareva et al. 1998; Pevzner et al. 2013). Recent studies suggest that the activity from Baidarny vents extended into the Late Glacial times (Pevzner et al. 2013).

Most of the Holocene eruptions were associated with the YSH eruptive center nested in the older collapse crater. YSH edifice is a cluster of lava domes (including the currently active one) 
and short lava flows. In addition, a few Holocene lava domes are located at the western slope of

126 Old Shiveluch (Karan domes), and a tuff ring recently revealed by erosion is positioned at the southwestern terminus of the Baidarny Spur (Fig. 2; Churikova et al. 2010). The exact number of former vents within the collapse crater is not known because some of them might be covered with later deposits while others might have been destroyed by numerous debris avalanches (Ponomareva et al. 1998).

Late Glacial-Holocene erupted products from Shiveluch are mainly pyroclastic deposits (bulk volume of $\sim 100 \mathrm{~km}^{3}$ ) with subordinate amount of lava (Gorbach and Portnyagin 2011). Pyroclastic deposits on Shiveluch slopes are interlayered with paleosol horizons and provide a nearly continuous record of the volcano's activity during the last $16 \mathrm{ka}$. The older pyroclastic sequence was probably removed from the volcano's slopes by glacial erosion. Sixty prominent pyroclastic units erupted since $\sim 11$ ka have been recognized and dated (Ponomareva et al. 2007). Preserved Holocene lava flows are rare (Gorbach and Portnyagin 2011) and extend $\leq 4 \mathrm{~km}$ from vent. They are too young to be dated by radiogenic methods so their eruption ages are uncertain. The eruptive history and magmatic evolution of this tectonically important volcanic center is therefore best examined using the pyroclastic deposits.

YSH eruptions are dominated by medium-K amphibole-bearing andesites which were fairly uniform throughout the Holocene, with the exception of two large basalt - basaltic andesite eruptions (Volynets et al. 1997; Ponomareva et al. 2007). Electron microprobe analyses of rhyolitic glass from thirteen Shiveluch tephras yielded similar compositions so these tephras could not be geochemically distinguished (Kyle at al. 2011). These data gave the impression of limited variations in the magma compositions at Shiveluch during the Holocene. However, some of the YSH pumices and lavas exhibit hybrid features formed by extensive mixing of evolved and primitive magmas (Volynets 1979; Gorbach and Portnyagin 2011). They are different from Old Shiveluch (including Baidarny) rocks, which exhibit limited evidence for magma hybridism

\section{(Gorbach et al. 2013).}

If the numerous tephra fall layers erupted from Shiveluch can be fingerprinted, they should make excellent markers for dating Holocene deposits and landforms up to distances of at least $350 \mathrm{~km}$ away from the volcano (Ponomareva et al. 2007). For example, a peat section $\sim 80 \mathrm{~km}$ southeast of Shiveluch that extends back to $\sim 6.8 \mathrm{ka}$ (Pevzner et al. 1998) contains at least 28 visible tephra layers assumed to be mainly from Shiveluch. Limited microprobe analyses of Shiveluch glass, however, have permitted only a few major Shiveluch tephras to be used as markers (e.g., Braitseva et al. 1983, 1991; Bourgeois et al. 2006; Goebel et al. 2003; Kozhurin et

158 al. 2006; O. Dirksen et al. 2011; V. Dirksen et al. 2013). On-going volcanological, 159 paleoseismological, archaeological and paleoenvironmental research in the area (Hulse et al. 
2011; Kozhurin et al 2006, 2014; Pendea et al. 2012; Pinegina et al. 2012; Portnyagin et al. 2009, 2011) would benefit if all the major tephra layers from Shiveluch are geochemically characterized, which will facilitate their use for dating and correlating various deposits and landforms.

Recent field work has permitted re-evaluation of the Shiveluch eruptive history over the last $16 \mathrm{ka}$. Recent erosion has exposed pyroclastic deposits on Shiveluch erupted between $\sim 16$ and $12 \mathrm{ka}$ (Pevzner et al. 2013). These deposits were produced by weak and moderate explosive eruptions attributed to activity at Baidarny Spur based on close resemblance of bulk tephra compositions to those of Baidarny lavas (Pevzner et al. 2013). The onset of the YSH was dated at $\sim 11.7 \mathrm{ka}$ (Gorbach and Portnyagin 2011; Pevzner et al. 2013).

\section{Proximal pyroclastic sequence}

Late Glacial-Holocene pyroclastic deposits on Shiveluch include tephra fall and pyroclastic density current deposits. The pyroclastic deposits are intercalated with paleosol horizons and debris avalanche deposits and form a near-continuous record spanning the last $\sim 16$ ka (Figs. 3 5; Online Resource 1). The pyroclastic deposits are best exposed in deep radial valleys (Fig. 2). Typical tephra fall deposits produced by plinian eruptions of YSH are andesitic pumice lapilli tuffs (Fig. 3) with estimated bulk volumes of up to $2-3 \mathrm{~km}^{3}$ (Ponomareva et al. 2007). Small tephras from YSH, such as those accompanying the current growth of lava dome, are composed of fine to coarse dark-pink, white, pale or gray ash. Most of these small tephras form discontinuous layers which are very similar in appearance, and are difficult to trace and correlate over the different sectors of the Shiveluch slopes.

Several basalt - basaltic andesite tephras erupted from YSH differ from the typical andesite tephra and may have been erupted from vents on the Baidarny Spur. Two major tephras were labeled the "dark package" and SHsp (Volynets et al. 1997). The "dark package" is a dark-gray stratified coarse ash of basaltic andesite composition (Volynets et al. 1997; Ponomareva et al. 2007). It was considered a main crater eruption until 2008, when its source - a tuff ring on the southwestern part of Baidarny Spur (Fig. 2) - was partly exposed by erosion (Churikova et al. 2010). The younger basaltic tephra, coded SHsp, has unique composition among the Kamchatka rocks. It is a high-K, high-Mg olivine- and phlogopite-bearing basalt (Volynets et al. 1997). Similar rocks occur in a dike on Baidarny Spur suggesting that the source of this eruption was also located at the Baidarny (Gorbach and Portnyagin 2011), however, it is not related to Baidarny or Southern vent. Four small tephras compositionally close to SHsp have recently been

193 found and also linked to an unknown source on the western slope of Old Shiveluch (Pevzner and Babansky 2011). 
Deposits of pyroclastic density currents are common at Shiveluch and are typically pumiceous ignimbrites and surge deposits. Some ignimbrites contain black scoria. Most of the ignimbrites are deposited to the south of the volcano.

Tephras from the Late Glacial Baidarny eruptive period are 1-10 $\mathrm{cm}$ thick layers of dull gray coarse cinders and fine ash (Fig. 4). These tephras have been found in a few outcrops at the western, eastern and southeastern slopes of the volcano. Because of the paucity of the outcrops containing these tephras and similarity of appearance and composition of these layers, we cannot correlate individual tephras between the sectors, so we refer to the whole package as "Baidarny cinders".

The Holocene YSH and Late Glacial Baidarny parts of the pyroclastic sequence are separated by $\sim 1-1.5$ meters of thinly bedded Baidarny-type cinders interlayered with $0.5-3 \mathrm{~cm}$ thick layers of fine to very fine white, light-gray or pink ash as well as with organic-rich paleosoils (Fig. 4c). The lower part of this succession is dominated by thin layers of ash-sized gray cinder while fine to very fine light-colored ash layers become more common higher in the succession. These tephra layers hereafter referred to as the "transition package" represent weak explosive activity related to transition from the Late Glacial Baidarny eruptive period to the YSH Holocene activity.

In addition to Shiveluch tephra, the sections around the volcano contain eight regional marker tephra layers from other Kamchatka eruptive centers (Ponomareva et al. 2007; Fig. 5),

214 easily identified in the field based on their color, grain size, and uniform thickness, as well as 215 numerous thin layers of dark-gray fine-grained cinders, mainly from Kliuchevskoi volcano.

216 Together with the earlier identified marker layers from Shiveluch they divide the Holocene tephra sequence into parts and help correlate tephra sections around the volcano.

\section{Methods}

$220 \quad$ Field stratigraphy

221 Many YSH tephra fall deposits have distinct dispersal axes and narrow elongated area of deposition (e.g., those of the 1964 and 1854 eruptions, see Fig. 2c in Kyle et al. 2011). These tephras can only be identified in one sector of the volcano. It means that any single tephra section on the volcano's slope is not representative of the whole eruptive history, and sections from all the sectors should be measured and correlated to each other. We have measured more than 200 sections through the pyroclastic deposits around the volcano, correlated them with the help of direct field tracing and radiocarbon dating (as in Ponomareva et al. 2007), and combined them to produce a summary section (Fig. 5; Online Resource 1). In addition to the sixty pyroclastic deposits (units), reported for YSH by Ponomareva et al. (2007), we have identified 
thirteen more YSH pyroclastic units and examined the transition between Baidarny and Young

231 Shiveluch activity. By unit in this paper (as well as in Ponomareva et al. 2007) we mean the pyroclastic deposits of an individual eruption clearly separated from neighbor pyroclastic layers by paleosols. The summary stratigraphy of pyroclastic deposits is the basis for the reconstruction

234 of the Shiveluch explosive activity during the last $16 \mathrm{ka}$. Even with the extensive coverage of measured stratigraphic sections, it is possible that some tephras were missed. Also some tephras could have been miscorrelated so the presented summary section is still an incomplete record of the Late Glacial-Holocene Shiveluch eruptions, and more eruptions could be identified during further studies.

We retain the numbering and informal codes for Shiveluch eruptions and pyroclastic units proposed by Braitseva et al. (1997), Ponomareva et al. (2007) and Pevzner et al. (2013). Newly identified YSH units are marked with the number of the underlying tephra plus the letters $\mathrm{a}, \mathrm{b}$. In some cases (units 23 - 27b and bottom of the section) we were not able to correlate deposits from different slopes of the volcano, therefore we show stratigraphies from each slope separately (Fig. 5; Online Resource 1). Three units above unit 26 found on the eastern slope are labeled with letters a, b, and c, because we do not know their stratigraphic relation with units 24 and 25 found on the western slope. Four early Holocene YSH tephras stratigraphically positioned below PL1 marker tephra are placed left of the main column and labeled 61(-1)-61(-4). Units that form the transition package are labeled T1-T5. Baidarny tephras are combined into four stratigraphic/age packages (B1-B4) (Fig. 5; Online Resource 1). Yellow color indicates units with large tephra fall deposits which are likely to work as regional marker layers. In this paper we classify tephras with bulk volume $>0.5 \mathrm{~km}^{3}$ as large, $0.5-0.1 \mathrm{~km}^{3}$ as moderate, and $<0.1 \mathrm{~km}^{3}$ as small. Dispersal axes of large tephras have been defined based on the location of the sites with their maximum thicknesses at a distance of $\leq 20 \mathrm{~km}$ from the volcano.

$\underline{\text { Radiocarbon dating and calibration }}$

256 Proximal tephra sequences at Shiveluch contain many organic-rich paleosol layers, charcoal and wood, which have been dated with the help of radiocarbon dating. Ponomareva et al. (2007) published 101 radiocarbon dates for the proximal sequence which were roughly calibrated to determine the approximate duration of active and repose periods but an accurate calculation of the age of each eruption was not performed. Since then twelve more dates for proximal sequence have been obtained (Pevzner et al. 2013, and this study). In order to estimate the ages of the eruptions we combined all available ${ }^{14} \mathrm{C}$ dates for proximal Shiveluch deposits (a total of 113, Online Resource 1) as well as 76 dates for marker tephra layers from other volcanoes obtained elsewhere (Braitseva et al. 1993, 1995; Bazanova, Pevzner 2001; Ponomareva et al. 2013) into a 
single Bayesian framework (Bronk Ramsey 2009) taking into account the stratigraphical ordering within and between the sites (Online Resource 2). Units (eruptions) were treated as boundaries. The lower age boundary for the Shiveluch tephra sequence $(15.8-16 \mathrm{ka})$ is based on calculations of soil accumulation rate (Pevzner et al. 2013). Whenever possible, the chronological ordering of the dates and units was defined explicitly based on stratigraphical reasoning, using the Sequence command. Separate sequences with shared markers were tied to the main sequence using OxCal's '=' linking function. Closely spaced dates and units for which the exact stratigraphical order could not be determined were put within Phases. Since the ${ }^{14} \mathrm{C}$ dates under unit 56 showed more scatter than dates above this unit, dates below said unit were assigned 5\% prior outlier probabilities (the model run did not finalize without this outlier labeling). The calibration curve used was the terrestrial northern hemisphere IntCal13 (Reimer et al. 2013)

This approach has allowed us to enhance the reliability and precision of the estimated calibrated age for most of the YSH eruptions whose tephra may serve as markers over a large area as well as for the regional marker tephra layers (Fig. 5; Online Resource 3). In this paper, we use calibrated ${ }^{14} \mathrm{C}$ ages in cal BP (calibrated years before AD 1950) except for the citations from old papers where the tephra ages were given in ${ }^{14} \mathrm{C}$ yrs BP. For loose (approximate) dates we are using designation ka (calibrated kyr before AD 1950; e.g., our record spans $\sim 16$ ka).

\section{$\underline{\text { Geochemical analysis }}$}

We have analyzed volcanic glass from 135 samples of proximal tephra-fall and pyroclastic density current deposits representing most of the identified Shiveluch eruptions (Online Resources 1 and 4). The samples were collected from outcrops around the volcano at a distance of 4-24 km from the modern dome (Fig. 2). Most of the samples are lapilli, eleven samples (mainly Baidarny cinders) are coarse to medium ash, and eight samples (mostly transition package) are fine to very fine ash (Online Resource 4). All samples were washed in distilled water and dried; lapilli were crushed. Each sample was examined under the microscope and representative unaltered glass shards were picked for the electron microprobe analysis. Backscattered electron images were obtained for representative tephra (Fig. 6).

Volcanic glass was analyzed using JEOL JXA 8200 electron microprobe equipped with five wavelength dispersive spectrometers including 3 high-sensitivity ones (2 PETH and TAPH) at GEOMAR (Kiel). The analytical conditions for glasses were $15 \mathrm{kV}$ accelerating voltage, $6 \mathrm{nA}$ current and $5 \mu \mathrm{m}$ electron beam size. Counting time was 5/10 s (peak/background) for $\mathrm{Na}$; 20/10s for Si, Al, Fe, Mg, Ca; 30/15 s for K, Ti, Cl, S; and 40/20 s for Mn and F. Standards used 
VG-A99) for Ti, Fe, Mg, Ca, P, rhyolitic glass (USNM 72854 VG568) for Si, Al, K, scapolite (USNM R6600-1) for $\mathrm{Na}, \mathrm{S}$ and $\mathrm{Cl}$, all from the Smithsonian collection of natural reference materials (Jarosevich et al. 1980), rhyolitic glass KN-18 (Mosbah et al. 1991) for F and synthetic rhodonite for Mn. Two to three analyses of the reference glasses and scapolite were performed at the beginning of analytical session, after every 50-60 analyses and at the end. The data reduction included on-line CITZAF correction (Armb 1995) and small correction for systematic deviations (if any) from the reference values obtained on standard materials. The latter correction did not exceed 5\% relative for all elements and allowed to achieve the best possible accuracy of the data and long-term reproducibility. The INTAV intercomparison of electron-beam microanalysis of glass by tephrochronology laboratories (Kuehn et al. 2011) revealed no systematic error for glasses compositions analyzed at GEOMAR lab (coded as lab \#12).

During data reduction we excluded EMP analyses with totals lower than 93 wt. \%, which 312 resulted from possible unevenness of sample surface, entrapment of voids or epoxy during 313 analysis of very small glass fragments. Contamination by epoxy resin has also been identified by unusually high measured chlorine concentrations, which resulted from 3-4 wt. \% of $\mathrm{Cl}$ in the epoxy resin used in the course of this study (Buehler EpoThin). Analyses contaminated by occasional entrapment of crystal phases, usually microlites of plagioclase, pyroxene or Fe-Ti oxides, were identified on the basis of excessive concentrations of $\mathrm{Al}_{2} \mathrm{O}_{3}, \mathrm{CaO}$ or $\mathrm{FeO}$ (and

$318 \mathrm{TiO}_{2}$ ), respectively, compared to the prevailing composition of glasses in every sample. Because

319 volcanic glasses can be hydrated over time during post-eruptive interaction with water or contain significant but variable amount of $\mathrm{H}_{2} \mathrm{O}$, not completely degassed during eruption, all analyses were normalized to $100 \%$ on an anhydrous basis. The original totals measured by EMP are given in Online Resource 4.

We have obtained a total of 1688 individual glass analyses from 135 samples collected from 41 sections. Typically we made 12 analyses per sample (Online Resource 4). Two tephras (units 7 and 9) did not contain fresh glass, and four earlier identified tephras (units 17, 26, 31 and 38) have not been analyzed because the samples were not available. In order to test the applicability of our proximal data for identification of distal tephras, we have also used 70 individual glass analyses for distal tephras obtained under the same analytical conditions (Online Resource 5). In discussion, we also used $63 \mathrm{XRF}$ and 22 wet chemistry analyses reported by

330 Ponomareva et al. (2007) and seven new XRF analyses on bulk Baidarny and YSH tephra

331 (Online Resource 6). All analyses of bulk tephra have been performed on pumice or cinder lapilli so they have not been influenced by eolian segregation and should be representative of bulk magma composition. 
336 Stratigraphy and ages of analyzed pyroclastic deposits

337 Fig. 5 presents a summary stratigraphy of proximal Shiveluch pyroclastic units and their

338 calibrated ages. Stratigraphic position of all the geochemically characterized samples and all the

339 radiocarbon dates for the proximal pyroclastic sequence are provided in Online Resource 1. Most

340 of the dates are in good agreement with the stratigraphy except for one case discussed below.

341 The section also includes marker tephra layers from other volcanoes. The 76 radiocarbon dates

342 for the marker tephra layers are placed in the Online Resource 2 (Oxcal code). One ${ }^{14} \mathrm{C}$ date

$343(9310 \pm 80)$ on a bulk sample below the PL1 marker tephra contradicts a new high quality date of

$34410,080 \pm 40$ for this tephra obtained elsewhere (Ponomareva et al. 2013) and makes the ages of

345 the units in this part of stratigraphy somewhat younger. We, however, retain all the published

346 dates in order to avoid arbitrary selection of the "good" dates.

$348 \quad$ Bulk compositions of Shiveluch tephra

349 Typical YSH pumice is light gray or light-yellow to tan, highly vesicular lacy andesite with 350 fluidal textures and $20-50 \%$ of phenocrysts (Fig. 6a-c). General mineral assemblage of andesitic

351 YSH tephra includes plagioclase, green hornblende, magnetite, ilmenite, ortho- and 352 clinopyroxene in various proportions. Some tephras (e.g., $\mathrm{SH}_{3}, \mathrm{SH}_{5}$ ) contain brown hornblende.

353 Olivine and apatite may occur as accessory minerals. YSH and Baidarny cinders are gray to 354 dark-gray, highly crystallized vesicular basalts - basaltic andesites abundant in microlites (Fig. 355 6d-f). "Dark package" cinders have the most massive and dense particles with rare rounded 356 vesicles (Fig. 6e). Overall, basalt - basaltic andesite cinders are more crystallized than andesitic 357 pumice and many of them contain only tiny $(\leq 5 \mu \mathrm{m})$ pockets of interstitial glass. Mineral 358 assemblage of the cinders is dominated by olivine, clinopyroxene and plagioclase. Tephra SHsp 359 (unit 28; Fig. 6d) contains phenocrysts of olivine, clinopyroxene, mica and green hornblende.

360 Late Glacial - Holocene Shiveluch lapilli are predominantly andesites and basaltic 361 andesites of medium-K compositions (Ponomareva et al. 2007; Fig. 7). SHsp tephra has $\mathrm{K}_{2} \mathrm{O}$ 362 contents $>1.6$ wt. $\%$ and is a high-K basalt very different from the rest of the pyroclastic deposits 363 (Fig. 7) (Volynets et al. 1997). Compositions of the pyroclastic deposits overlap closely with the 364 YSH and Baidarny lavas (Gorbach and Portnyagin 2011), although lava represents only a few 365 short periods of activity whereas the pyroclastic deposits were formed in over 80 eruptions 366 spanning the last $\sim 16$ ka (Fig. 7; Online Resource 1). Late Glacial Baidarny cinders have 367 distinctively higher $\mathrm{TiO}_{2}, \mathrm{Al}_{2} \mathrm{O}_{3}$ and $\mathrm{Na}_{2} \mathrm{O}$, and lower $\mathrm{MgO}$ contents at given $\mathrm{SiO}_{2}$ compared to 368 the YSH tephra (Fig. 7), and are similar to the compositions of lavas from the Baidarny and 369 Southern vents (Gorbach et al. 2013). Very tight and linear trends of the YSH pumice and lava 
compositions on variation diagrams of major elements are argued to originate via fractional crystallization and concurrent mixing of mafic and silicic magmas as well as via crystal accumulation in evolved melt (e.g., Dirksen et al. 2006; Humphreys et al. 2008; Gorbach and Portnyagin 2011; Gorbach et al. 2013).

$\underline{\text { Volcanic glass compositions }}$

376 Volcanic glass compositions from all Shiveluch tephra range from $\sim 58$ to 80 wt. $\% \mathrm{SiO}_{2}$ and fall into two major groups: low- and high-Si (Figs. 8 and 9). Glasses from Baidarny cinders have predominantly trachyandesitic and trachydacitic compositions with $62-71.5$ wt. \% $\mathrm{SiO}_{2}$ ("low-Si glasses" further on). Glasses from YSH tephras are mostly rhyolitic with $\mathrm{SiO}_{2}=71.5-80$ wt. \% ("high-Si glasses" further on). Some low-Si glasses (58-71.5 wt. \% $\mathrm{SiO}_{2}$ ) also occur during the YSH activity, mostly in minor and moderate eruptions, and in two large basalt - basaltic andesite tephras units 28 (SHsp) and 46 ("dark package"). Most of these glasses fall into trachyandesitic and trachydacitic fields with subordinate amount of glass compositions in the upper part of the dacite field. Both trachydacitic and rhyolitic glasses are equally present in small tephras from the transition package.

On Harker variation diagrams Shiveluch glasses exhibit well-defined trends of decreasing $\mathrm{FeO}, \mathrm{TiO}_{2}$ and $\mathrm{MgO}$ contents with decreasing $\mathrm{SiO}_{2}$ (Fig. 9). $\mathrm{Na}_{2} \mathrm{O}$ contents reach maximum at $\mathrm{SiO}_{2}$ of $\sim 65$ wt. $\%$ and then decrease with increasing $\mathrm{SiO}_{2} . \mathrm{K}_{2} \mathrm{O}$ increase and $\mathrm{Al}_{2} \mathrm{O}_{3}$ and $\mathrm{CaO}$ decrease with increasing $\mathrm{SiO}_{2}$ but are more scattered compared to other major elements. On the $\mathrm{K}_{2} \mathrm{O}-\mathrm{SiO}_{2}$ diagram the majority of rhyolitic glasses falls into the medium-K field (Fig. 9) with $\mathrm{K}_{2} \mathrm{O}$ contents between 2.4 and 3.7 wt. \%, the range being larger than that of $2.5-3$ wt. \% identified by Kyle et al. (2011) for thirteen YSH tephras. A small population of high-K $\left(\mathrm{K}_{2} \mathrm{O}>4\right.$ wt. \%) rhyolitic glasses is found in small tephras from the transition package.

Low-Si glasses from Shiveluch have medium- to high-K compositions. Baidarny glasses form a trend from $\sim 62$ to 71 wt. \% $\mathrm{SiO}_{2}$. Glasses from YSH units 43 and 46 ("dark package") fit into the same trend but also include glasses with lower $\mathrm{SiO}_{2}$ contents $\left(60-62\right.$ wt. \% $\left.\mathrm{SiO}_{2}\right)$. $\mathrm{The}$ lowest $\mathrm{SiO}_{2}$ contents (58-60 wt. \%) occur in glass from unit 61(-2) stratigraphically positioned below PL1 marker tephra (Fig. 5; Online Resource 1). Glasses from Baidarny and three above mentioned units 43, 46, and 61(-2) are higher in alkali and lower in $\mathrm{CaO}$ contents than glasses from most of the other YSH cinders; only a few of the latter partly fit into the Baidarny-dark package trend with the glasses from unit 36a being the closest. Glasses from SHsp and similar minor tephra (unit 36b) stand apart from other Shiveluch glasses and have distinctly high-K glass with highly variable $\mathrm{K}_{2} \mathrm{O}$ contents (3.69-5.96 wt. \%) and $\mathrm{SiO}_{2}$ range between 59.8 and 66.9 wt. 
The majority of the YSH andesitic tephra units have quite homogeneous $\left(\mathrm{SiO}_{2}\right.$ variations within 2 wt. \%) rhyolitic glass compositions (Fig. 10a); a few have variable glass compositions usually organized in trends or in different populations (Fig. 10b). On Harker variation diagrams homogeneous glasses form individual clusters: some of those differ in $\mathrm{K}_{2} \mathrm{O}$ and/or other oxides from each other while the others have overlapping compositional fields (Fig. 10a). Among the heterogeneous glasses, the most pronounced variations in $\mathrm{SiO}_{2}$ contents (64-74 wt. \%) are observed in SHdv fall deposits (unit 34) (Fig. 10b); shorter trends are characteristic for tephra

412 from units $6\left(\mathrm{SH}_{2}\right), \mathrm{b}, 56,57$ and some others. Mixed material with two or three glass 413 populations occurs in some ignimbrites (Online Resource 4). Most of Baidarny cinders have 414 slightly variable glass compositions forming trends in the trachyandesitic - trachydacitic field 415 (Fig. 9).

417 Temporal variations of glass composition in Shiveluch tephra

418 Low-Si glass compositions predominated during the Late Glacial activity between $\sim 16$ and 12.8 419 ka. In products of Holocene eruptions, low-Si glasses occur a number of times, most frequently between $\sim 4$ and $8.4 \mathrm{ka}$, when the YSH andesitic eruptions were relatively rare (Fig. 11). High-Si glasses typical for the YSH activity first appeared at $\sim 12.7 \mathrm{ka}$ in thin layers of fine to very fine white ash in the transition package. During the YSH lifetime, the compositions of high-Si glasses have exhibited alternating periods of decreasing or increasing $\mathrm{SiO}_{2}$ (Fig. 11). Well expressed periods of decreasing $\mathrm{SiO}_{2}$ took place at $\sim 11-9.9,8.5-7.7,5.6-4.9$ and 4-3 ka, and $1.5 \mathrm{ka}$-present (except for $\mathrm{AD} 2001$ glasses). Increasing $\mathrm{SiO}_{2}$ was characteristic for periods of $\sim 9.9-8.5,4.9-4$, and 2.9-1.5 ka. The systematic changes of $\mathrm{SiO}_{2}$ resulted in semi-continuous wave-like pattern of glass compositions through time (Fig. 11).

Variations of other major element oxides strongly correlating with $\mathrm{SiO}_{2}$ content in Shiveluch glasses $\left(\mathrm{MgO}, \mathrm{FeO}, \mathrm{TiO}_{2}, \mathrm{CaO}, \mathrm{Al}_{2} \mathrm{O}_{3}\right)$ also exhibit a wave-like pattern through time.

430 Variations of $\mathrm{K}_{2} \mathrm{O}$ in glasses are somewhat different from other major element oxides (Fig. 11). 431 Among the large tephras (except for the SHsp), the most high-K glass compositions come from vitreous tephras erupted during the initial stages of the YSH activity between 11.1 and $8.4 \mathrm{ka}$ (Figs. 9 and 11). The majority of these high-Si glasses have $\mathrm{K}_{2} \mathrm{O}>3$ wt. $\%$ whereas glasses from more recent eruptions $(8.4-1.8 \mathrm{ka})$ have predominantly $<3$ wt. $\% \mathrm{~K}_{2} \mathrm{O}$.

The significant variability of Shiveluch glasses suggests that many of the units can be discerned from each other based on their glass compositions. The wave-like changes of major oxides through time, however, indicate that (1) some glass compositions may be repeated within different time intervals, and (2) glasses from the neighbor units in the stratigraphic succession may have very similar compositions. 
Comparison of Shiveluch tephra compositions to those from other Kamchatka tephra

Proximal YSH bulk lapilli have high MgO (2.3-6.8 wt. \%), Cr (47-520 ppm), Ni (18-106 ppm) and Sr (471-615 ppm) and low Y (<18 ppm) (Ponomareva et al. 2007). These features distinguish YSH erupted products from other Kamchatka Holocene pyroclastic deposits. Some of these features have also been described for bulk samples of distal YSH tephra and used for correlations of distal tephra layers. Braitseva et al. (1997) reported high Cr (98-124 ppm), Ni (26-30 ppm) and Sr (415-461 ppm) and low Y (12-13 ppm) in two samples of the YSH fine ash. Kyle et al. (2011) proposed $\mathrm{Cr}$ contents of $>50 \mathrm{ppm}$ (the highest among other silicic tephras in Kamchatka) and $\mathrm{La} / \mathrm{Yb}$ ratio of 4-10 as the most diagnostic characteristics for identifying YSH bulk distal tephra.

For identification of distal tephras, however, results derived from bulk compositions may be inconclusive because of eolian differentiation and contamination with terrigenic material. Volcanic glass is the predominant component of most tephras and its composition is normally used for chemical fingerprinting and distal correlations of tephra (e.g., Lowe 2011). The main major element characteristics of the YSH rhyolitic glass reported earlier is medium $\mathrm{K}_{2} \mathrm{O}$ contents (2.5-3.0 wt. \%) (Kyle et al. 2011). This is clearly not enough to identify Shiveluch tephra in distal localities which is why Kyle et al. (2011) suggested complementing glass data with the trace element data on bulk samples.

Our new data allow us to further refine specific features of Shiveluch glasses, which help to discern Shiveluch pyroclastic deposits from other major Kamchatka tephras. Shiveluch glasses have characteristically high $\mathrm{Na}_{2} \mathrm{O}$, low $\mathrm{CaO}$ and consequently low $\mathrm{CaO} /\left(\mathrm{Na}_{2} \mathrm{O}+\mathrm{K}_{2} \mathrm{O}\right)$ at any given $\mathrm{SiO}_{2}$ (Fig. 12a) corresponding to calc-alkaline series in classical definition of Peacock (1931) $\left[\mathrm{CaO} /\left(\mathrm{Na}_{2} \mathrm{O}+\mathrm{K}_{2} \mathrm{O}\right)<1\right.$ at $\mathrm{SiO}_{2}=60$ wt. \%]. Unlike Shiveluch, many other Kamchatkan volcanoes produced glasses which belong to calcic series. Such glass compositions are characteristic for major tephras from Avachinsky, Iliinsky and Ksudach volcanoes (Fig. 12a). Noticeably, Shiveluch bulk rock compositions also have the strongest calc-alkaline specifics compared to other volcanoes in the Central Kamchatka depression and likely in all Kamchatka (e.g., Portnyagin et al. 2007).

The strong calc-alkaline affinity is, however, not a unique feature of Shiveluch glasses. Glasses from some other major silicic and intermediate tephras in Kamchatka also fall into, or close to the Shiveluch field on the $\mathrm{CaO} /\left(\mathrm{Na}_{2} \mathrm{O}+\mathrm{K}_{2} \mathrm{O}\right)$ vs. $\mathrm{SiO}_{2}$ diagram (Fig. 12a). These are glasses from KHG, KHD, KRM, KO, KZ, OP, and OPtr marker tephras (Kyle et al. 2011) overlapping with high-Si Shiveluch glasses, and those from Plosky volcano (Ponomareva et al. 
2013) overlapping with intermediate Baidarny glasses. KHD and KO glasses have lower, and those of OP and OPtr - higher $\mathrm{K}_{2} \mathrm{O}$ content than Shiveluch glasses at given $\mathrm{SiO}_{2}$ (Table 1; Fig. 12b). Medium-K glasses from $\mathrm{KZ}$ tephra are distinguished by their elevated $\mathrm{CaO}(>1.5 \mathrm{wt} . \%)$. Glasses from KRM tephra have elevated $\mathrm{Cl}(>0.20$ wt. \%) and those from $\mathrm{KHG}-$ low $\mathrm{Cl}(<0.08$ wt. \%) contents (Fig. 12c). Intermediate Baidarny glasses can be distinguished from those of Plosky volcano on the basis of high $\mathrm{K}_{2} \mathrm{O}$, low $\mathrm{Cl}\left(<0.1\right.$ wt. \%) and high $\mathrm{P}_{2} \mathrm{O}_{5}(>0.5$ wt. \%) contents in the latter (Fig. 12, Table 1). Thus, strongly calc-alkaline medium-K characteristics of Shiveluch glasses along with moderate $\mathrm{Cl}, \mathrm{CaO}$ and low $\mathrm{P}_{2} \mathrm{O}_{5}$ allow reliable discrimination of silicic Shiveluch tephras from the majority of other large Holocene tephras of Kamchatka.

Identification of Shiveluch tephra in distal localities and their correlations to proximal tephra units

487 The majority of distal Shiveluch tephras have equivalent proximal pumice fall deposits (Braitseva et al. 1997; Ponomareva et al. 2007). Fingerprinting of these proximal units, therefore, is most important in order to provide a reference for correlations with distal tephra. Two Holocene basalt - basaltic andesite tephras (SHsp and dark package) were also dispersed over large areas (Volynets et al. 1997) and are important for the reference set. Some YSH small tephras like the 2010 ash (Ponomareva et al. 2012) or co-ignimbrite fall deposits may also form distinct layers over the distances of $80 \mathrm{~km}$ so their compositions should also be considered. The dispersal of Baidarny cinders is not mapped but based on their proximal thicknesses (Fig. 4) and field tracing they may well be found over $30 \mathrm{~km}$ from the volcano.

Some YSH tephras have been recognized on Bering and Attu Islands and at Okhotsk coast of Kamchatka (Figs. 12d and 13), 350-850 km to the east and $400 \mathrm{~km}$ southwest from the volcano (Kirianov et al. 1990; Melekestsev and Kurbatov 1998; Pevzner 2003, 2010; Kyle et al. 2011). Such distal findings, however, are few because of the proximity of the seas in the east and paucity of measured terrestrial sections in the northern and western directions from the volcano. In addition, most of these correlations were based on field tracing and ${ }^{14} \mathrm{C}$ dating and only very few were supported by microprobe glass analyses (Kyle et al. 2011; Dirksen et al. 2011).

At distances of 100-200 km from the volcano, typical andesitic YSH tephra is coarse to fine-grained ash of specific "salt-and-pepper" color where "salt" consists of pumiceous grains and/or plagioclase and "pepper" - of dark-colored minerals (Braitseva et al. 1997). This is consistent with the crystal-rich nature of the YSH magmas. Farther downwind these tephras normally still retain visible grains and do not acquire significant amount of very fine ash. These distal tephras mainly correlate with non-graded proximal pumice layers with distinct dispersal axis. Bulk composition of YSH tephra normally changes downwind from andesite (lapilli) to 
510 basaltic andesite (coarse ash enriched in mineral grains) and then to andesite-dacite (dominantly

511 vitric fine ash) (Braitseva et al. 1997). Isopach maps or areas of dispersal have been published

512 for thirteen YSH andesitic tephras (Kyle et al. 2011) and for two major YSH basalt - basaltic

513 andesite tephras ("dark package" and SHsp, units 46 and 28, respectively) (Volynets et al. 1997).

514 We have characterized glass from most of proximal large pyroclastic deposits

515 geochemically, refined their ages, and shown their main dispersal sectors and axes (Fig. 5; for

516 orientation the north-based directions are labeled on Fig. 2). All data are compiled in Online

517 Resource 4, which provides a practical tool for comparison of glass compositions from unknown

518 tephra with our database of Shiveluch proximal glasses. This file contains description page; our

519 complete data set of Shiveluch EMP glass compositions from proximal tephras; sheet with

520 calculated mean compositions of glasses from Shiveluch units and data on their ages and

521 dispersal; sheet to enter user's data; two sheets for comparing unknown tephra with Shiveluch

522 glasses (SC-test and t-test); service tables; sheets SC matrix and SC matrix (large) located at the

523 end of the table. Data on the large tephras dispersal are given in the sheet named "all average".

524 Those include dispersal sectors at a distance of $\leq 20 \mathrm{~km}$ from the volcano (in degrees from north

525 clockwise) and main dispersal axes based on the maximum thickness of each tephra at the same

526 distance. These axes are also indicated on Fig. 5 and in Online Resource 1.

527 Our comparison with Shiveluch glasses is performed using two alternative approaches:

528 similarity coefficient and statistical $t$-test. The similarity coefficient (SC) between two mean

529 compositions is calculated following a formulation by Borchardt et al. (1972) commonly used in

530 tephrochronology (e.g., Lowe 2011; Davies et al. 2012). SC is calculated for 10 elements (Si, Ti,

$531 \mathrm{Al}, \mathrm{Fe}, \mathrm{Mg}, \mathrm{Ca}, \mathrm{Na}, \mathrm{K}, \mathrm{P}, \mathrm{Cl}$ ) and for all Shiveluch units compared to unknown glass.

532 Optionally, $\mathrm{P}$ can be excluded from the calculations when its concentration approaches detection

533 limit of microprobe analyses and thus can influence SC significantly. Mn is not included in

534 calculations because this element correlates strongly with Fe, has low concentrations in glasses

535 and is usually determined with relatively low precision. According to Froggatt (1992) two

536 analyses are considered to be equivalent when $\mathrm{SC}>0.92$.

537 The statistical $t$-test (Microsoft Excel) is performed for the case of two-tail unequal

538 distribution for 11 elements. The null-hypothesis of inequality is rejected at critical $t$-value of

539 0.05. The number of elements for which the null-hypothesis is rejected defines $\mathrm{T}_{11}$ value. The

540 higher the $\mathrm{T}_{11}$ value the more similar are two mean glass compositions. In practice, very similar

541 glasses have $\mathrm{T}_{11}>6$, that is, means for 6 elements of 11 in consideration are statistically

542 indistinguishable on $95 \%$ confidence level.

$543 \quad$ Both tables calculating SC and $t$-values have options for "fine tuning" allowing to narrow

544 the searchable database. For example, when working with thick Shiveluch layers at distant 
545 localities it can be reasonable to exclude minor eruptions. Entering the direction to the sampling 546 site from Shiveluch allows one to further exclude eruptions that sent tephra in other directions.

547 Another very effective way to narrow an age interval is to provide any age constraints available 548 from direct dating of the deposits or from stratigraphy. Finally, settings of critical SC and $\mathrm{T}_{11}$ 549 values can be changed to higher or lower values. Based on our testing, the tables are effective in 550 defining one or a few Shiveluch eruptions which fit all above mentioned criteria. In everyday 551 work with the database, it is quite common that both SC and $t$-test point to one Shiveluch 552 eruption as an ultimate source of unknown tephra. Below we describe examples of a few long553 distance correlations done with the help of the new database and major conclusions derived from 554 these results.

Sheets SC matrix and SC matrix (Large) located at the end of the Online Resource 4 show Shiveluch units which are similar in glass compositions. Two large basalt - basaltic andesite tephras, SHsp (unit 28) and "dark package" (unit 46) have unique compositions and can be used as markers in distal localities. From 41 large pumiceous tephras, only few have unique glass compositions: 14, 15, 34 (SHdv), 45, 47, 55. All others have more or less strongly expressed geochemical similarity to some other YSH units, and their identification in distal sites requires further constraints from stratigraphy, age and dispersal axes. Proximal glass data, however,

564 Examples of long-distance correlations of Shiveluch tephra

565 Based on our data for major proximal YSH tephras including their ages, glass chemistry, and stratigraphic position between regional marker tephra layers, we can now ascribe some "unknown tephras" analyzed on-land and in marine cores to YSH. Here we provide a few examples of such correlations, which allow us to better estimate the distance of dispersal of the largest YSH tephras and provide the basis for estimates of tephra volumes and magnitudes of the eruptions. These data also demonstrate practical results of using our new database of proximal Shiveluch glasses (Online Resource 4).

1. Fine-grained tephra dubbed "Lower yellow" (LY) was long known in the Eastern volcanic front between Kronotsky volcano and Bolshoi Semiachik caldera (Fig. 13). It was locally dated at $\sim 9300{ }^{14} \mathrm{C}$ yrs and used for dating of volcanic features at Krasheninnikov and Kikhpinych volcanoes (Braitseva et al. 1989; Ponomareva et al. 1990). The source of this tephra was not known although sources of major silicic tephras had already been identified by this time (Braitseva et al. 1995, 1997). Microprobe analyses of glass have allowed us to identify the same tephra on the slopes of Kliuchevskoi volcano where it was medium sand size (Fig. 14a; 
580 for Shiveluch, but it had lower $\mathrm{SiO}_{2}$ and higher $\mathrm{K}_{2} \mathrm{O}$ contents than then known for Shiveluch 581 tephra, and did not fit into the geochemical portrait of tephra from any other volcano (Kyle et al. 582 2011). With our current extensive coverage for the proximal Shiveluch tephra, we can identify the "LY" as one of the YSH early Holocene tephras (Figs. 10a and 14a). Comparison of glass compositions from each of the "LY" samples to the proximal YSH dataset shows that up to three large YSH tephras may geochemically match it. Consideration of dispersal axis (southwards) and age interval (early Holocene), however, allows us to single out unit 58 as the most probable match ( $\mathrm{SC}_{10}$ values of $0.929-0.961$, and $\mathrm{T}_{11}$ of $\left.6-8\right)$. The resulting distribution map (Fig. 13) prompts that "Lower yellow" is one of the larger eruptions from Shiveluch.

2. $\mathrm{SH}_{5}$ tephra is one of the markers from YSH dispersed to the south of the volcano (Braitseva et al. 1997). Its previous age estimate was based on erroneous correlation of distal tephra dispersed to the south with the proximal tephra unit 24 at the northwestern slope of the volcano dated at $\sim 2550{ }^{14} \mathrm{C}$ yrs (Ponomareva et al. 2007). By comparing the glass data for both tephras, we were able to untangle the proximal stratigraphy and correlate the distal tephra to YSH unit 21 dated at $\sim 1850$ cal BP (Fig. 14b). Comparison of glass compositions from distal $\mathrm{SH}_{5}$ tephra and unit 21 yielded high $\mathrm{SC}_{10}(0.953)$ and $\mathrm{T}_{11}(10)$ values while comparison of the same tephra to unit 24 yielded $\mathrm{SC}_{10}(0.918)$ and $\mathrm{T}_{11}$ (4). The younger age for the $\mathrm{SH}_{5}$ tephra allows us to reconsider the ages of many important volcanic events in the Kliuchevskoi volcanic group whose ages have been estimated relative to $\mathrm{SH}_{5}$ : Bezymianny eruptive period $\mathrm{BI}$ with its largest explosive eruption (Braitseva et al. 1991); eruption of the Kliuchevskoi famous high-Mg cinder cones (Auer et al. 2009), active period in the Tolbachik monogenetic lava field (Braitseva et al. 1983), etc.

3. Very fine rhyolitic hornblende-bearing ash was found in two cores at the Shrishov Ridge (Bering Sea) in association with the early Holocene PL2 cindery tephra from Plosky volcano, which serves as a marker in the summary Shiveluch section and fits between units 56 and 57 (Fig. 5) (Ponomareva et al. 2013). Rhyolitic glasses in both cores correspond to calc-alkaline medium-K rhyolites with moderate $\mathrm{Cl}$ and $\mathrm{CaO}$, and low $\mathrm{P}_{2} \mathrm{O}_{5}$ contents, which is consistent with their origin from YSH (Online Resources 4 and 5). In the core SO201-2-77KL (Fig. 13; N $56.3305^{\circ} \mathrm{E} 170.6997^{\circ}$ ), both PL2 tephra and YSH glasses are found at the depth of $116-117 \mathrm{~cm}$. Formal comparison of rhyolitic glass from this layer to the proximal dataset (Online Resource 4)

610 shows that it passes the test for similarity with the glasses from units 51, 54 and 56 with the best 611 match to unit $56\left(\mathrm{SC}_{10}=0.965\right.$ and $\left.\mathrm{T}_{11}=10\right)$ (Fig. 14c). Considering its stratigraphic proximity to 612 PL2 tephra in the proximal sequence, unit 56 is likely the source of this marine ash (Fig. 14c).

613 In the core SO201-81KL (pilot) (N 56.7165 $\mathrm{E} 170.4962^{\circ}$ ) rhyolitic glass was found at the 614 depths of 10-13 and 14-17 cm in association with PL2 tephra, which is more abundant in the 
615 lower sample (Ponomareva et al. 2013). Rhyolitic glasses have typical YSH medium-K 616 composition (Fig. 14c). It is not clear whether all these glasses come from a single eruption or 617 belong to several different units. As a single unit, these glasses compositionally match five large 618 YSH tephras (units 1, 4, 6, 27, and 36). All these units, however, are younger than $\sim 5.6 \mathrm{ka}$. 619 Taking into account a close association of the glasses with PL2 tephra dated at $10.2 \mathrm{ka}$, we tend 620 to favor unit $59(10.7 \mathrm{ka})$ with dispersal axis to the east as a correlative for at least glasses from 621 the 14-17 cm level $\left(\mathrm{T}_{11}=8\right)$ (Fig. 14c). Other glasses may belong to different units.

622 Exact correlations of submarine tephra to certain YSH units require more analytical work 623 on the former, but it is important that at least two different early Holocene YSH tephras were 624 found at a distance of 560-580 km away from the source. These are the first ever findings of 625 Shiveluch tephra in marine cores. Presence of different tephras in the same layers in the marine cores may result from low accumulation rate of the sediments and/or contamination during the coring of semi-liquid Holocene deposits.

4. Kyle et al. (2011) attributed three tephra samples (95-01/1, 95-01/2 and 95-06/1) collected on Attu Island (western Aleutians) to YSH (Fig. 13). If this correlation is correct, it would increase the estimates of dispersal distance for Shiveluch tephra from $350 \mathrm{~km}$ (Ponomareva et al. 2007) or $560-580 \mathrm{~km}$ (see above) to $850 \mathrm{~km}$. The three samples are very close geochemically (Fig. 14d). All of them fit into an age interval of $\sim 3000-5100{ }^{14} \mathrm{C}$ yr BP (Kyle et al. 2011). The Attu tephras have lower $\mathrm{K}_{2} \mathrm{O}$ contents than the majority of the YSH glasses (Fig. 14d). Only one of those samples (95-01/2) passed the formal test on similarity with any of the proximal units, however, a probable match (unit 6) is far younger (764 cal BP) and has a SSW- and not E-directed dispersal axis. At this stage correlation of the Attu tephras with Shiveluch is tenuous and we leave open the possibility that these tephras may have come from some closer source in the Aleutians.

640 Geochemical variability of Young Shiveluch glasses

641 Significant geochemical variability of glasses from the YSH tephras, which facilitates their usage 642 in tephrochronology, is rather unexpected result given the relatively short time interval of the 643 volcanic activity (Holocene) and earlier data by Kyle et al. (2011) who reported a rather small 644 compositional variability of Shiveluch glasses. It is therefore worthwhile to analyze possible 645 petrological reasons for the compositional variability of glasses and rocks documented in our 646 study.

Here we refer to pyroclastic and effusive Shiveluch rocks as close compositional analogues of magmas that existed at depth and have undergone degassing upon eruption. Volcanic glasses represent a (partially) degassed residual melt quenched during eruption. The glasses can 
approach the composition of melt in magma chamber or be more evolved due to late crystallization, which may occur immediately before eruption and during magma transport to the surface (e.g. Blundy and Cashman 2001). The compositions of YSH rocks and glasses can thus be interpreted in terms of a number of petrogenetic processes including: 1) crystallization, 2) crystal removal, sorting or accumulation, 3) mixing of variably fractionated magmas, and 4) mixing with magmas of different geochemical type. The relative role of these processes in the petrogenesis of YSH lavas was discussed by Gorbach and Portnyagin (2011) and Gorbach et al. (2013).

Crystallization is a major petrogenetic process occurring either due to magma cooling or decompression and water degassing from magma (e.g., Eichelberger 1995; Blundy et al. 2006; Portnyagin et al. 2012). In most Shiveluch magmas, crystallizing assemblage of minerals is represented by ortho- and clinopyroxene, plagioclase, hornblende, oxides and apatite (Gorbach and Portnyagin, 2011). Effects of crystallization of this low-Si and low-K assemblage are clearly seen in the composition of glasses, which often exhibit short $\left(\mathrm{SiO}_{2}\right.$ range of 2-3 wt. \%) but well defined trends of coherently increasing $\mathrm{SiO}_{2}$ and $\mathrm{K}_{2} \mathrm{O}$ as crystallization proceeds (Fig. 10b). Crystallization of magma results in evolving melt and increasing amount of crystals but has no effect on bulk magma composition and thus can be suggested for tephras of identical bulk composition with different composition of glasses.

Processes of crystal removal, sorting and accumulation are related to physical movement of crystals relative to melt and each other, and therefore they have no effect on the composition of melt but are able to change proportion between the melt and amount of crystals in magma. For example, Gorbach and Portnyagin (2011) showed that compositional trend of Young Shiveluch lavas can be well explained by selective separation of mafic minerals, primarily, hornblende and oxides relative to plagioclase.

Processes of mafic and evolved magma mixing are well documented for YSH lavas and pyroclastics (Volynets 1979; Humphreys et al. 2006; Dirksen et al. 2006; Gorbach and Portnyagin, 2011). Effect of magma mixing on volcanic glasses is expressed in shifting glass compositions to lower $\mathrm{SiO}_{2}$ along mixing trend, as a result of direct mixing of mafic and silicic melts, or more likely along the crystallization trend due to dissolution of phenocrysts at increasing temperature. Incomplete mixing with basaltic magmas prior to eruption is also evident from a common occurrence of banded pumices and coexistence of low- and high-Si glasses in andesitic pyroclastic rocks. Effects of mixing on bulk magma composition are similar to that for glasses. Hybrid rocks have lower $\mathrm{SiO}_{2}$ content and plot along linear mixing trends. There is also 
and distinctively high $\mathrm{Cr}$ content (>50 ppm, Ponomareva et al. 2007) in YSH tephra cannot be explained by crystallization processes but require persistent admixture of mafic $\mathrm{Cr}$-rich material to Shiveluch andesites.

The processes outlined above are mainly responsible for shifting glass and/or magma compositions along (or close to) crystallization trends and unable to explain significant variability of Shiveluch glasses in $\mathrm{K}_{2} \mathrm{O}$ content at any given $\mathrm{SiO}_{2}$. In order to explain this variability, we propose mixing of different geochemical type magmas, "normal" medium- $\mathrm{K}_{2} \mathrm{O}$ and high- $\mathrm{K}_{2} \mathrm{O}$, in magma-feeding system beneath Young Shiveluch. High- $\mathrm{K}_{2} \mathrm{O}$ tephras of distinctive composition form the SHsp layer. Additional evidence for widespread involvement of high- $\mathrm{K}_{2} \mathrm{O}$ melts comes from the presence of dacitic melt inclusions in plagioclase with up to 6.5 wt. $\% \mathrm{~K}_{2} \mathrm{O}$ found in YSH rocks (Tolstykh et al. 2000). The high-K silicic melts can result from extensive crystallization of high-K basalts (SHsp tephra), crustal assimilation (Gorbach and Portnyagin 2011) or low pressure "dry" fractionation leading to stronger enrichment in $\mathrm{K}_{2} \mathrm{O}$ compared to hydrous high pressure fractionation (e.g., Botcharnikov et al. 2008). More conclusive evidence about the origin of the K-rich component in YSH magmas can be likely obtained with the help of trace element and isotope studies.

Concurring effects of the four processes described above can readily explain the large variability of YSH glasses. These processes are rather common in the genesis of island-arc andesites (e.g., Gorbach et al. 2013 and references therein), and thus tephras of other frequently erupting andesitic volcanoes can be similarly distinguished with the help of systematic study of compositions of volcanic glass and whole rocks. Although andesitic tephra are frequently considered to be difficult for geochemical fingerprinting (Shane et al. 2005; Donoghue et al. 2007; Lowe 2011), our results provide new perspective and petrologic background for using such tephras in constraining detailed tephrostratigraphy in many volcanically active regions on continental margins.

\section{The origin of regular temporal variations of Young Shiveluch glasses}

Geochemical studies of the detailed tephra record for individual volcanoes are few (e.g., Donoghue et al. 2007; Oladottir et al. 2008; Turner et al. 2009) though they permit to study evolution of volcanoes with great details and sometimes show certain regular temporal patterns in the eruptive records (Oladottir et al. 2008). Our work at Shiveluch and Kliuchevskoi volcanoes also shows that both volcanoes exhibit wave-like changes of $\mathrm{SiO}_{2}$ contents in glass from rapidly quenched tephras during Holocene roughly correlating in time between the volcanoes (Portnyagin et al. 2009, 2011). Both volcanoes have been erupting continuously with little (Shiveluch) or no (Kliuchevskoi) significant repose periods so their eruptions provide 
almost continuous temporal record of the composition of magmas (bulk rocks) and their melts (glasses) under these volcanoes.

As described in previous chapter the most profound effect on $\mathrm{SiO}_{2}$ content in volcanic glasses have two counteracting processes, crystallization and mixing with mafic melt. Interaction between these two processes on a long time scale can provide a reasonable explanation for the wave-like pattern of $\mathrm{SiO}_{2}$ in volcanic glass of Young Shiveluch tephra. No such clear trend is seen in the composition of bulk tephras (Fig. 11).

Low-pressure crystallization during magma transport to the surface and eruption can certainly affect the composition of volcanic glasses (e.g., Blundy et al. 2006). This process alone is, however, unlikely to result in wave-like variability of $\mathrm{SiO}_{2}$ in Shiveluch glasses as this would imply alternating periods of more or less extensive low-pressure crystallization during the Shiveluch history without clear reason and without correlation to the magnitude of the eruptions. Alternatively, the wave-like variations can reflect the temporal evolution of melt composition in magma chamber prior to eruption and be interpreted in terms of the evolution of periodically replenished - continuously fractionated magma chamber (O'Hara 1977).

As much of the glass variations can be explained by counteracting processes of mixing and crystallization, the temporal trends from more to less silicic compositions ( 11-9.9, 8.5-7.7, 5.64.9, 4-3 ka, and 1.5 ka-present) (Fig. 11) can be explained when mafic replenishments are frequent and/or more voluminous so that they drive melt composition in magma chamber toward more mafic one against the effect of crystallization. The opposite trend from less to more silicic compositions may imply that the effect of crystallization becomes more important and overwhelms the effect of mafic replenishments, which could be less frequent or less abundant at certain interval of time. The wave-like pattern of $\mathrm{SiO}_{2}$ variations may thus reflect alternating periods of high and low frequency/volume of mafic magma supply to deep magma chamber beneath Shiveluch. The onsets of four of five presumed periods of high mafic magmas supply ( 11-9.9, 8.5-7.7 and 4-3 ka, and 1.5 ka-present) strikingly coincide in time with known periods of enhanced volcanic activity in Kamchatka (Fig. 11) (Braitseva et al. 1995; Kozhurin et al. 2006; Pevzner et al. 2013; Ponomareva et al. 2013). This synchroneity suggests that the ascents of deeper magmas may have been caused by regional stress redistribution rather than by local processes at Shiveluch.

Implications for Shiveluch eruptive history

The activity of Shiveluch has persisted throughout the Late Glacial - Holocene times and was non-uniform in time both in terms of eruption frequency and composition of erupted products.

754 Exclusively Baidarny-type basaltic andesite tephras were erupted between $\sim 16$ and $\sim 12.8$ ka, 
which represented the activity that had started in the late Pleistocene (Gorbach et al. 2013). A major divide in the Late Glacial - Holocene eruptive history was the arrival of high-Si melts at $\sim 12.7 \mathrm{ka}$, which likely marked the onset of the YSH activity. The first small high-Si tephras might have been related to the andesitic dome- and lava-producing eruptions at the initial stages of the YSH activity (Gorbach and Portnyagin 2011; Pevzner et al. 2013). Young Shiveluch powerful explosive activity started at $\sim 11.1 \mathrm{ka}$ BP. Since then, high-Si glasses prevailed in the erupted tephras (Fig. 8).

Bulk Baidarny cinders have compositions close to Baidarny and Southern vents lavas (Fig. 7). They have significantly lower $\mathrm{MgO}, \mathrm{Cr}$ and higher $\mathrm{SiO}_{2}, \mathrm{Al}_{2} \mathrm{O}_{3}, \mathrm{Na}_{2} \mathrm{O}, \mathrm{K}_{2} \mathrm{O}$ contents compared to the YSH unit 46 ("dark package") (Fig. 7; Online Resource 6). Glass compositions in Baidarny cinders and in the "dark package", however, are very close (Fig. 9; Online Resource 4). Melt inclusions found in minerals from Baidarny cinders and from the "dark package" have similar compositions (Pevzner et al. 2013). This implies that the "dark package" tephras are likely enriched in mafic crystals but otherwise cogenetic with Baidarny cinders and lavas. We interpret this as persisting presence (envolvement) of the Baidarny-type magmas during the YSH activity.

\section{Conclusions}

Here we present a state-of-the-art dataset of compositions and ages of Late Glacial-Holocene proximal tephras from the dominantly andesitic Shiveluch volcano (Kamchatka). The dataset is accompanied by an interactive table for comparison of unknown glasses to those from proximal tephra units (Online Resource 4). These data are used to reconstruct the eruptive history and magmatic evolution of Shiveluch during the last $\sim 16 \mathrm{ka}$, and to assist in the identification of distal Shiveluch tephras. We explicitly envisage that our knowledge of the Shiveluch eruptive history could be updated in the future once new ${ }^{14} \mathrm{C}$ dates are added to our existing compilation and/or more tephra units are recognized and characterized geochemically.

As a result, we have obtained a nearly continuous record of glass compositions for Shiveluch tephras spanning the last $\sim 16 \mathrm{ka}$. This record has allowed us to reveal that Young Shiveluch rhyolitic glasses exhibit wave-like variations in $\mathrm{SiO}_{2}$ and some other elements contents through time that may reflect alternating periods of high and low frequency/volume of mafic magmas supply to deep magma chamber beneath the volcano. A wave-like pattern of $\mathrm{SiO}_{2}$ and other elements variations through time has earlier been found for basaltic Kliuchevskoi volcano located $75 \mathrm{~km}$ southeast of Shiveluch (Portnyagin et al. 2009, 2011). Baidarny-type tephras were erupted mostly during the Late Glacial time (16-12.8 ka) but also persisted into the Holocene as subordinate (except for the "dark package" unit) admixture in prevailing andesitic 
tephras. The described compositional variability of Shiveluch glasses facilitates geochemical

791 fingerprinting of distal Shiveluch tephras and their use as a dating tool in paleovolcanological, paleoseismological, paleoenvironmental, and archaeological studies.

At Shiveluch volcano we have encountered several well known problems related to andesitic tephra and proximal tephra sequence such as complex stratigraphy with about eighty individual pyroclastic units; similar appearance of many pumiceous tephras; high vesicularity and crystallinity of pumices and cinders; heterogeneity of glass compositions. In our case, extensive stratigraphic work (more than 200 measured sections), direct tracing of major tephra layers between the sectors, and detailed radiocarbon dating helped to compile a summary stratigraphy. A 5- $\mu \mathrm{m}$ beam size made it possible to successfully analyze even tiny glass pockets in pumices and cinders. Glass heterogeneity in some tephras, e.g., SHsp, helps to uniquely identify them.

We suggest working on proximal deposits, where available, in order to reconstruct nearcontinuous record of past eruptions and provide a better reference for identification and correlation of distal tephras. Dating and calibration of high resolution proximal tephrostratigraphy permit to narrow the age interval for each tephra; this refined age can be further used for more precise dating of various deposits. This research is important for the longterm forecast of eruptions and volcanic hazard assessment, and contributes to both global and regional tephra databases.

809

Acknowledgements. This study was supported by the Russian-German project 811 KALMAR, funded by the German Ministry of Science and Education (BMBF), Russian 812 Foundation for Basic Research (grant \#13-05-00346) and the Otto Schmidt Laboratory for Polar 813 and Marine Research. The large part of the samples was collected thanks to the field grant from 814 the National Geographic Society. The authors thank Mario Thöner (GEOMAR) for the help with 815 the microprobe analysis, and Natalia Gorbach and Sergei Khubunaya for tephra samples from 816 AD 2001 and 2005 eruptions. Philip Kyle acknowledges support from the Division of Polar 817 Programs, NSF (USA). Thorough reviews of two anonymous reviewers are very much 818 appreciated.

\section{References}

821 Armb JT (1995) CITZAF: A package of correction programs for the quantitative electron 822 microbeam X-ray analysis of thick polished materials, thin films, and particles. Microbeam 823 Analysis 4:177-200 
824 Auer S, Bindeman I, Wallace P, Ponomareva V, Portnyagin M (2009) The origin of hydrous, high- $\delta{ }^{18} \mathrm{O}$ voluminous volcanism: diverse oxygen isotope values and high magmatic water contents within the volcanic record of Klyuchevskoy volcano, Kamchatka, Russia. Contrib Mineral Petrol 157/2:209-230

Bazanova LI, Pevzner MM (2001) Khangar: One more active volcano in Kamchatka, Transactions (Doklady) of the Russian Academy of Sciences, Earth Sciences, 377A:307-310

Belousov A. B. (1995) The Shiveluch volcanic eruption of 12 November 1964-explosive eruption provoked by failure of the edifice. J Volcanol Geotherm Res 66:357-365

Blundy J, Cashman K (2001) Ascent-driven crystallisation of dacite magmas at Mount St Helens, 1980-1986. Contrib Mineral Petrol 140(6):631-650

Blundy J, Cashman K, Humphreys M (2006) Magma heating by decompression-driven crystallization beneath andesite volcanoes. Nature 443:76-80

Borchardt G, Aruscavage P, Millard HJ (1972) Correlation of the Bishop ash, a Pleistocene marker bed, using instrumental neutron activation analysis. J Sediment Petrol 42:301-306

Botscharnikov RE, Almeev RR, Koepcke J, Holtz F (2008) Phase relations and liquid lines of descent in hydrous ferrobasalt - Implications for the Skaergaard intrusion and Columbia River flood basalts. J Petrol 49(9):1687-1727. doi:1610.1093/petrology/egn1043

Bourgeois J, Pinegina TK, Ponomareva VV, Zaretskaia NE (2006) Holocene tsunamis in the southwestern Bering Sea, Russian Far East and their tectonic implications. The Geol Soc Amer Bull, 11 (3/4):449-463. doi: 10.1130/B25726.1

Braitseva OA, Melekestsev IV, Ponomareva VV (1983) Age divisions of the Holocene volcanic formations of the Tolbachik Valley. In: Fedotov SA (ed) The great Tolbachik fissure eruption: geological and geophysical data 1975-1976, Cambrige Earth Sci Series, pp 83-95

Braitseva OA, Florenskii IV, Ponomareva VV, Litasova SN (1989) The history of the activity of Kikhpinych volcano in the Holocene. Volcanol Seismol 7(6):845-872

Braitseva OA, Melekestsev IV, Bogoyavlenskaya GE, Maksimov AP (1991) Bezymianny volcano: eruptive history and activity dynamics. Volcanol Seismol 12(2):165-194

Braitseva OA, Sulerzhitsky LD, Litasova SN, Melekestsev IV, Ponomareva VV

$$
\text { Radiocarbon dating and tephrochronology in Kamchatka. Radiocarbon 35:463-476 }
$$

Braitseva OA, Melekestsev IV, Ponomareva VV, Sulerzhitsky LD (1995) The ages of calderas, large explosive craters and active volcanoes in the Kuril-Kamchatka region, Russia. Bull Volcanol 57(6):383-402

Braitseva OA, Ponomareva VV, Sulerzhitsky LD, Melekestsev IV, Bailey J (1997) Holocene key-marker tephra layers in Kamchatka, Russia. Quat Res 47(2):125-139

Bronk Ramsey C (2009) Bayesian analysis of radiocarbon dates. Radiocarbon 51(1):337-360 
Churikova TG, Gordeichik BN, Belousov AB, Babansky AD (2010) Finding of the eruptive center for basalts at Shiveluch volcano. In: Gordeev EI (ed.) Proceedings of the All-Russia conference in honor of the 75th anniversary of the Kamchatka volcanological station. Petropavlovsk-Kamchatsky. Institute of Volcanology and Seismology FED RAS

Davaille A, Lees JM (2004) Thermal modelling of subducted plates: tear and hotspot at the Kamchatka corner. Earth Planet Sci Lett 226:293-304

Davidson J, DeSilva S (2000) Composite volcanoes. In Sigurdsson H (ed) Encyclopedia of Volcanoes: San Diego, CA, Academic Press, pp 663-682

Davies SM, Wastegård S, Rasmussen TL, Johnsen SJ, Steffensen JP, Andersen KK, Svensson A (2008) Identification of the Fugloyarbanki tephra in the NGRIP ice-core: a key tie-point for marine and ice-core sequences during the last glacial period. J Quat Sci 23:409-414

Davies SM, Abbott PM, Pearce NJG, Wastegård S, Blockley SPE (2012) Integrating the INTIMATE records using tephrochronology: rising to the challenge. Quat Sci Rev 36:11-27

Dirksen O, Humphreys MCS, Pletchov P, Melnik O, Demyanchuk Y, Sparks RSJ, Mahony S (2006) The 2001-2004 dome-forming eruption of Shiveluch volcano, Kamchatka: Observation, petrological investigation and numerical modelling. J Volcanol Geotherm Res

Dirksen O, van den Bogaard C, Danhara T, Diekmann B (2011) Tephrochronological investigation at Dvuh-yurtochnoe lake area, Kamchatka: Numerous landslides and lake tsunami, and their environmental impacts. Quat Int 246:298-311

Dirksen V, Dirksen O, Diekmann B (2013) Holocene vegetation dynamics in Kamchatka, Russian Far East. Rev Palaeobot Palynol 190:48-65

Donoghue SL, Vallance J, Smith IEM, Stewart RB (2007) Using geochemistry as a tool for correlating proximal andesitic tephra: case studies from Mt Rainier (USA) and Mt Ruapehu (New Zealand). J Quatern Sci 22(4):395-410

Dvigalo VN (1984) Growth of the dome in the crater of Shiveluch volcano in 1980-1981 according to photogrammetric data. Volcanol Seismol 2:104-109 (in Russian)

Eichelberger JC (1995) Silicic volcanism: Ascent of viscous magmas from crustal reservoirs. Annu. Rev. Earth Planet. Sci 23:41-63

Fedotov SA, Zharinov NA, Dvigalo VN, Seliverstov NI, Khubunaya SA (2004) The 2001-2004 eruptive cycle of Shiveluch volcano. Volcanol Seismol 6:3-14 (in Russian).

Froggatt PC (1992) Standardization of the chemical analysis of tephra deposits: report of the ICCT working group. Quat Int 13/14:93-96 
894 Goebel T, Waters MR, Dikova M (2003) The archaeology of Ushki Lake, Kamchatka, and the 895 Pleistocene peopling of the Americas. Science 301:501505

896 Gorbach NV, Portnyagin MV (2011) Geology and petrology of the lava complex of Young 897 Shiveluch volcano (Kamchatka). Petrology 19(2):136-168

898 Gorbach NV, Portnyagin MV, Tembrel I (2013) Volcanic structure and composition of Old 899 Shiveluch volcano, Kamchatka. J Volcanol Geotherm Res 263:193-208. doi: $900 \quad$ http://dx.doi.org/10.1016/j.jvolgeores.2012.12.012

901 Gorelchik VI, Shirokov VA, Firstov PP, Chubarova OS (1997) Shiveluch volcano: seismicity, 902 deep structure and forecasting eruptions (Kamchatka). J Volcanol Geotherm Res 78: 21-132

903 Gorshkov GS, Dubik YuM (1970) Gigantic directed blast at Shiveluch volcano 904 (Kamchatka).Bull Volcanol 34:261-288

Hulse EL, Keeler DM, Zubrow EBW, Korosec GJ, Ponkratova IY, Curtis C (2011) A

906

907 preliminary report on archaeological fieldwork in the Kamchatka Region of Russia. Sibirica $1: 48-74$

Humphreys MCS, Blundy JD, Sparks RSJ (2006) Magma evolution and open-system processes at Shiveluch Volcano: Insights from phenocryst zoning. J Petrol 47 (12):2303-2334. doi: 10.1093/petrology/eg1045

Humphreys MCS, Blundy JD, Sparks RSJ (2008) Shallow-level decompression crystallisation and deep magma supply at Shiveluch Volcano. Contrib Mineral Petrol 155(1):45-61

Jarosewich EJ, Nelen JA, Norberg JA (1980) Reference samples for electron microprobe analysis. Geostandards Newsletter, 4:43-47

Khubunaya SA, Zharinov NA, Muravyev YaD, Ivanov VV, Boloyavlenskaya GE, Novgorodtseva TYu, Demyanchuk YuV, Budnikov VA, Fazlullin S. M. (1995) 1993 eruption of Shiveluch volcano. Volcanol Seismol 17:1-20

Kirianov VYu, Egorova IA, Litasova SN (1990) Volcanic ash on Bering Island (Commander Islands) and Kamchatkan Holocene eruptions. Volcanol Seismol 8:850-868

Kozhurin A, Acocella V, Kyle PR, Lagmay FM, Melekestsev IV, Ponomareva VV, Rust D, Tibaldi A, Tunesi A, Corazzato C, Rovida A, Sakharov A, Tengonciang A, Uy H (2006) Trenching active faults in Kamchatka, Russia: paleoseismological and tectonic implications. Tectonophysics 417:285-304

Kozhurin AI, Pinegina TK, Ponomareva VV, Zelenin EA, Mikhailyukova PG (2014) Rate of collisional deformation in Kamchatsky Peninsula, Kamchatka Geotectonics 48(2):122-138 
Kyle PhR, Ponomareva VV, Rourke Schluep R (2011) Geochemical characterization of marker tephra layers from major Holocene eruptions in Kamchatka, Russia. Int Geol Rev 53(9):1059-1097

932

Le Bas MJ, Le Maitre r W, Streckeisen A, Zanettin B (1986) A chemical classification of volcanic rocks based on the total alkali-silica diagram. J Petrol 27:745-750

934

Lowe DJ (2011) Tephrochronology and its application: A review. Quat Geochronol 6:107-153

Melekestsev IV, Volynets ON, Ermakov VA, Kirsanova TP, Masurenkov YuP (1991) Shiveluch volcano. In: Fedotov SA, Masurenkov YuP (eds) Active volcanoes of Kamchatka, vol 1. Nauka Press, Moscow, pp 84-103

Melekestsev IV, Kurbatov AV (1998) Frequency of large paleoearthquakes at the northwestern coast of the Bering Sea and in the Kamchatka basin during late Pleistocene/Holocene time. Volcanol Seismol 19:257-267

Mosbah M, Metrich N, Massiot P (1991) PIGME fluorine determination using a nuclear microprobe with application to glass inclusions. Nucl Instrum Methods B58:227-231

O'Hara MJ (1977) Geochemical evolution during fractional crystallization of a periodically refilled magma chamber. Nature 266:503-507

Oladottir B, Sigmarsson O, Larsen G, Thordarson T (2008) Katla volcano, Iceland: magma composition, dynamics and eruption frequency as recorded by Holocene tephra layers. Bull Volcanol 70 (4):475-493

Pendea IF, Ponomareva V, Bourgeois J, Korosec G, LaSelle S-P, Ponkratova I, Ferguson C, Fraser R, Keeler D, Zubrow E (2012) Late Glacial to Holocene Environmental History of eastern Kamchatka Peninsula, North Pacific. Abstracts of the Geological Association of Canada Conference, May 2012, St John's, NL.

Peacock MA (1931) Classification of igneous rocks. J Geol 39:54-67

Pevzner MM (2003) Tephrostratigraphic reference layers in the Holocene soil sections of the southern part of the Sredinny Range and some peculiarities in ${ }^{14} \mathrm{C}$ dating of the peats. Volcanol Seismol 4:1-15

Pevzner MM (2010) The northern boundary of volcanic activity of Kamchatka in Holocene. Bulletin of Kamchatka Regional Association "Educational-scientific Center". Earth Sciences. 1/15:231-258 [In Russian] http://www.kscnet.ru/kraesc/2010/2010 15/2010_15 eng.html

Pevzner MM, Ponomareva VV, Melekestsev IV (1998) Chernyi Yar - reference section of the Holocene ash markers at the northeastern coast of Kamchatka. Volcanol Seismol 19(4):389406 
963

964

965

966

967

968

969

970

971

972

973

974

975

976

977

978

979

980

981

982

983

984

985

986

987

988

989

990

991

992

993

994

995

996

Pevzner MM, Babansky AD (2011) Basaltic activity episode at $4600-3100{ }^{14} \mathrm{C}$ years BP (33701400 cal BC) at andesitic Shiveluch volcano, Kamchatka. Abstracts of the International Biennial Workshop on Subduction Processes emphasizing the Japan-Kurile-KamchatkaAleutian Arcs (JKASP). Petropavlovsk-Kamchatsky, Russia, August 25-30. P. 262-263

Pevzner MM, Tolstykh ML, Babansky AD, Kononkova NN (2013) Reconstruction of the magmatic system in the Shiveluch volcanic massif as a result of large-scale collapses of its edifice in the late Pleistocene-early Holocene. Doklady Earth Sciences 448 (1):35-37

Pevzner MM, Tolstykh ML, Babansky AD, Layer P., Volynets A.O. (2014) First data on the isotope age and composition of the parental melts of the initial stage of the Shiveluch volcanic massif. Volcanism and associated processes. Materials of the annual conference celebrating the Volcanologist Day. Petropavlovsk-Kamchatsky, Institute of Volcanology and Seismology, pp 104-107

http://www.kscnet.ru/ivs/publication/volc_day/2014/art16.pdf [In Russian]

Pinegina TK, Kozhurin AI, Ponomareva VV (2012) Seismic and tsunami hazard for Ust'Kamchatsk village, Kamchatka, based on paleoseismological data. Bulletin of Kamchatka Regional Association "Educational-scientific Center". Earth Sciences. 1/19:138-159 [In Russian] http://www.kscnet.ru/kraesc/2012/2012 19/2012 19 eng.html

Ponomareva VV (1990) The history of Krasheninnikov volcano and the dynamics of its activity. Volcanol Seismol 9:714-741

Ponomareva VV, Pevzner MM, Melekestsev IV (1998) Large debris avalanches and associated eruptions in the Holocene eruptive history of Shiveluch Volcano, Kamchatka, Russia. Bull Volcanol 59:490-505

Ponomareva VV, Kyle PR, Pevzner MM, Sulerzhitsky LD, Hartman M (2007) Holocene eruptive history of Shiveluch volcano. Kamchatka Peninsula. In: Eichelberger J, Gordeev E, Kasahara M, Izbekov P, Lees J (eds) Volcanism and Subduction: The Kamchatka Region, American Geophysical Union Geophysical Monograph Series, American Geophysical Union, Washington DC, vol 172, pp 263-282

Ponomareva VV, Portnyagin MV, Melnikov DV (2012) Composition of tephra from modern (2009-2011) eruptions of the Kamchatka and Kuril Islands volcanoes. Bulletin of Kamchatka Regional Association "Educational-scientific Center". Earth Sciences. 2/20:7-21 [In Russian] http://www.kscnet.ru/kraesc/2012/2012_20/2012_20_eng.html

Ponomareva V, Portnyagin M, Derkachev A, Pendea IF, Bourgeois J, Reimer PJ, GarbeSchönberg D, Krasheninnikov S, Nürnberg D (2013) Early Holocene M 6 explosive eruption from Plosky volcanic massif (Kamchatka) and its tephra as a link between terrestrial 
997

998

999

1000

1001

1002

1003

1004

1005

1006

1007

1008

1009

1010

1011

1012

1013

1014

1015

1016

1017

1018

1019

1020

1021

1022

1023

1024

1025

1026

1027

1028

1029

1030

and marine paleoenvironmental records. J Int Earth Sci 102(6):1673-1699. doi: 10.1007/s00531-013-0898-0

Portnyagin M, Bindeman I, Hoernle K, Hauff F (2007) Geochemistry of primitive lavas of the Central Kamchatka Depression: Magma Generation at the Edge of the Pacific Plate. In: Eichelberger J, Gordeev E, Kasahara M, Izbekov P, Lees J (eds) Volcanism and Subduction: The Kamchatka Region, American Geophysical Union Geophysical Monograph Series, American Geophysical Union, Washington DC, vol 172, pp 199-239

Portnyagin M, Ponomareva V, Bindeman I, Hauff F, Krasheninnikov S, Kuvikas O, Mironov N, Pletchova A, van den Bogaard C, Hoernle K (2009) Millennial variations of major and trace element and isotope compositions of Klyuchevskoy magmas, Kamchatka. Terra Nostra 1:6465

Portnyagin M, Mironov N, Ponomareva V, Bindeman I, Hauff F, Sobolev A, Kayzar T, Garbe-Schönberg D, Hoernle K (2011) Arc magmas from slab to eruption: the case of Kliuchevskoy volcano. Mineralogical Magazine. Abstracts of the 2011 Goldcshmidt Conference, Prague, p 1661; http://www.minersoc.org

Portnyagin M, Hoernle K, Mironov NL (2012) Contrasting compositional trends of rocks and olivine-hosted melt inclusions from Cerro Negro volcano (Central America): implications for decompression-driven fractionation of hydrous magmas. Int J Earth Sci. doi:

10.1007/s00531-012-0810-3

Reimer PJ, Bard E, Bayliss A, Beck JW, Blackwell PG, Bronk Ramsey C, Buck CE, Cheng H, Edwards RL, Friedrich M, Grootes PM, Guilderson TP, Haflidason H, Hajdas I, Hatté1 C, Heaton TJ, Hoffmann DL, Hogg AG, Hughen KA, Kaiser KF, Kromer B, Manning SW, Niu M, Reimer RW, Richards DA, Scott EM, Southon JR, Staff RA, Turney CSM, van der Plicht J (2013) IntCal13 and Marine13 Radiocarbon Age Calibration Curves 0-50,000 Years cal BP. Radiocarbon 55(4):1869-1887

Shane P, Nairn IA, Smith VC (2005) Magma mingling in the $\sim 50$ ka Rotoiti eruption from Okataina Volcanic Centre: implications for geochemical diversity and chronology of large volume rhyolites. J Volcanol Geotherm Res 139:295-313

Tolstykh ML, Naumov VB, Babanskii AD et al. (2000) Chemical composition, trace elements, and volatile components of melt inclusions in minerals from andesites of the Shiveluch Volcano, Kamchatka. Geochem Int 38 (Suppl 1):S123-S132

Turner M, Bebbington M, Cronin S, Stewart R (2009) Merging eruption datasets: building an integrated Holocene eruptive record for Mt Taranaki, New Zealand. Bull Volcanol 71(8):903-918 
Volynets ON (1979) Heterotaxitic lavas and pumices and the problem of magma mixing. In: Sobolev VS (Ed.) Problems of Deep Magmatism, pp 181-197, Nauka Press, Moscow (in Russian)

Volynets ON, Ponomareva VV, Babansky AD (1997) Magnesian basalts of Shiveluch andesite volcano, Kamchatka. Petrology 5(2):183-196

Zharinov NA, Bogoyavlenskaya GE, Khubunaya SA, Demyanchuk YuV (1995) A new eruption cycle of Shiveluch volcano, 1980-1993. Volcanol Seismol 17:21-30

Zharinov NA, Demyanchuk YuV (2013) Large explosive eruptions of Shiveluch volcano, Kamchatka resulting in partial destruction of the extrusive dome (February 28, 2005 and

Table 1 Comparison of glass compositions from major Kamchatka tephras to Shiveluch proximal data

\section{Figure captions}

Fig. 1 Shiveluch volcanic massif seen from southwest. Inset shows the location of Shiveluch volcano (yellow star) in relation to major tectonic features: Aleutian arc to the east and Kuril-Kamchatka arc to the south

Fig. 2 Satellite image of Shiveluch volcanic massif consisting of the late Pleistocene Old Shiveluch (Old SH) volcano, destroyed by a collapse crater, and the currently active Young Shiveluch (YSH) eruptive center nested in the latter. Southwestern part of Old Shiveluch (Baidarny Spur) is formed by lava flows from Baidarny and Southern vents marked with blue diamonds. Red diamonds show positions of the Holocene Shiveluch vents. A tuff ring at the southwestern slope of Baidarny Spur produced a large tephra (the "dark package", see text for discussion). Yellow circles show positions of tephra sections with analyzed tephra samples. Small black circles show all measured sections in the area. River valleys mentioned in the text are labeled in white. Numbers around the frame show north-based directions from the Young Shiveluch crater used for determining the tephra fall axes (Online Resource 4)

Fig. 3 Typical outcrops of the Holocene tephra sequence on the Shiveluch slopes. a - tephra sequence overlying pyroclastic density current deposits in Mutny Creek valley, northwestern slope of the Shiveluch edifice, $13.5 \mathrm{~km}$ from the modern dome; $\mathbf{b}$ - major pumice fall layers in Dry Ilchinets valley, southeastern sector of Shiveluch slope, $12 \mathrm{~km}$ from the modern dome. Labels of major tephra units as in Fig. 5, Online Resources 1-4. SHsp and SHdv are important YSH marker tephras discussed in the text. Marker tephra 
layers from other volcanoes: KHG $(\sim 7.85 \mathrm{ka})$ - Khangar; KZ ( 8.1 ka; highlighted with a yellow line) - Kizimen; PL2 ( 10.2 ka) and PL1 ( 11 ka) - Plosky volcanic massif

Fig. 4 Outcrops of Late Glacial - Holocene deposits in Dry Ilchinets valley (southeastern sector of Shiveluch slope, $11 \mathrm{~km}$ from the modern dome). a-b - Holocene tephra sequence overlying two debris avalanche deposits (DAD), and Late Glacial sequence sandwiched between them; c - Late Glacial tephra sequence between the two DADs. The lower part of the sequence contains only gray or oxidized Baidarny cinders (coarse and fine sands, and rare lapilli). The upper part (transition package labeled TP, see text for discussion) is dominated by $0.5-3 \mathrm{~cm}$ thick layers of white very fine silicic ash related to the onset of the Young Shiveluch active period $(\sim 12.7 \mathrm{ka}$ BP) but also contains a few thin layers of Baidarny cinders. Numbers of the analyzed samples from this outcrop are shown left and right of the photo; black and yellow labels show samples taken in 1996 and 2011, respectively. Radiocarbon dates (Pevzner et al. 2013) are shown in red. Dates within each box have been obtained on different fractions of the same sample

Fig. 5 Simplified summary stratigraphy of the Late Glacial-Holocene pyroclastic sequence on the Shiveluch slopes. Deposits from individual YSH eruptions (in this paper referred to as units) are shown with boxes and labeled left of those. Large tephras (bulk volumes ca. $>0.5$ $\mathrm{km}^{3}$ ) are highlighted in yellow. Small tephras forming the "transition package" are shown with green dotted lines and labeled T1-T5 (from top to bottom). Late Glacial Baidarny tephras are combined into four packages (B1-B4) highlighted in blue. In some cases (units $23-27 \mathrm{~b}$ and the bottom of the YSH sequence) we were not able to correlate deposits from different slopes of the volcano, therefore we show the stratigraphies from each slope separately. Pyroclastic material analyzed in this paper is indicated inside each box: $\mathrm{f}$ tephra fall deposits, i - ignimbrite. Units 17, 26, 31, and 38 marked "n/a" have not been analyzed because the samples were not available. In units 7 and 9 marked "n/d" no fresh glass has been detected. Codes for marker tephra layers from Shiveluch used in previous research are the same as in Ponomareva et al. (2007) and are labeled in magenta left and right of the boxes. "Lower yellow" is one of the marker tephra layers from Shiveluch identified in this paper. Regional marker tephra layers are shown with thick magenta lines and labeled in magenta, from top to bottom: BZ1956 - Bezymianny volcano AD 1956 tephra; $\mathrm{KS}_{1}$ and $\mathrm{KS}_{2}-$ Ksudach volcano tephra (Braitseva et al. 1995, 1997); KL Kliuchevskoi (Braitseva et al. 1995); KHG - Khangar (Bazanova and Pevzner 2001); KZ Kizimen (Braitseva et al. 1997); PL1 and PL2 - Plosky volcanic massif (Ponomareva et al. 2013). Calibrated ages of the Shiveluch pyroclastic units and regional marker tephra layers (weighted mean of all age estimates for each layer) are given right of the boxes or magenta 
lines. Direction of dispersal for large tephras is provided right of the ages. The lower age boundary for the Late Glacial part of the Shiveluch tephra sequence (15.8-16 ka) is based on calculations of soil accumulation rate (Pevzner et al. 2013). For complete summary stratigraphy and analyzed samples IDs see Online Resource 1

Fig. 6 Backscattered electron images of selected Shiveluch tephra. a-c - Young Shiveluch pumiceous tephra: a - $\mathrm{SH}_{1}$ (unit 4, sample 757-1), b - SH2800 (unit b, sample 775-8), c early Holocene high-K pumice (sample 775-25); d-f - cinders: d - SHsp (unit 28, sample 757-20); e - "dark package" (unit 46, sample K01-17); f - Baidarny cinder (sample 970573). For stratigraphic position of the samples see Online Resource 1

Fig. 7 Compositions of Shiveluch lava and proximal lapilli tephra. In TAS plot fields shown according to Le Bas et al (1986): B - basalt, BA - basaltic andesite, A - andesite, D -

Fig. 8 Histograms of $\mathrm{SiO}_{2}$ contents in glasses from tephra erupted at different stages of Late dacite, BTA - basaltic trachyandesite, TA - trachyandesite, TD - trachydacite. In $\mathrm{K}_{2} \mathrm{O}$ $\mathrm{SiO}_{2}$ plot low-, medium-, and high-K fields are shown after Gill (1981). Data on tephra are from Ponomareva et al. (2007) and this study, and data on lava compositions are from Gorbach and Portnyagin (2011) and Gorbach et al. (2013). The labels on the diagrams indicate two basalt - basaltic andesite tephras (SHsp and "dark package") discussed in the text Glacial-Holocene Shiveluch activity show that glass compositions fall into two major groups: glasses from Baidarny and YSH cinders have $258-71.5$ wt. \% $\mathrm{SiO}_{2}$ (low-Si glasses), and glasses from YSH pumices are mostly rhyolitic with $\mathrm{SiO}_{2}=71.5-80$ wt. \% (high-Si glasses). Dotted gray line shows the boundary between the two groups

Fig. 9 Compostions of Shiveluch glasses plotted versus $\mathrm{SiO}_{2}$ content. Small gray dots in background illustrate a compositional range of glasses from Holocene Kamchatka tephras (Kyle et al. 2011; Ponomareva et al. 2012, 2013; V. Ponomareva and M. Portnyagin, unpublished). Fields of different rock types in TAS (see Fig. 7 for abbreviations) and $\mathrm{K}_{2} \mathrm{O}$ vs. $\mathrm{SiO}_{2}$ plots are shown after Le Bas et al. (1986) and Gill (1981), respectively. Error bars (2sigma) characterize $95 \%$ uncertainty of individual data points as calculated from multiple standard measurements by propagating the errors to the average composition of Shiveluch glass. The labels on the diagrams indicate two basalt - basaltic andesite tephras (SHsp and "dark package") discussed in the text

Fig. 10 Examples of homogeneous (a) and heterogeneous (b) glass compositions found in different YSH pumice units (color circles). Labels of the units have same colors as the symbols for corresponding glass compositions, and are the same as in Fig. 5 and Online Resources). For the units used as markers in previous research (e.g., Braitseva et al. 1997; 
Pevzner et al. 1998; Kyle et al. 2011) their codes are provided in brackets. Gray circles show glass compositions in all the YSH tephra

1138 Fig. 11 Temporal variations in $\mathrm{SiO}_{2}$ and $\mathrm{K}_{2} \mathrm{O}$ contents in Shiveluch glasses and bulk lapilli

Fig. 12 Comparison of Shiveluch glass compositions to those from other large Holocene Kamchatka tephras (see discussion in the text). Fields and averages for glass compositions from different tephras from Kyle et al. (2011) and Ponomareva et al. (2013). A map (d) shows sources of the largest Holocene Kamchatka tephras. Tephra codes: AV 1 , IAV2 Avachinsky volcano; IL - Iliinsky volcano; KHD - Khodutkinsky crater; KHG -Khangar volcano; KO - Kurile Lake caldera; KRM - Karymsky caldera; $\mathrm{KS}_{1}, \mathrm{KS}_{2}, \mathrm{KS}_{3}, \mathrm{KSht}_{3}$ Ksudach eruptive center; KZ - Kizimen volcano; OP - Barany Amphitheater crater at Opala volcano; OPtr - Chasha crater; PL - Plosky eruptive center

Fig. 13 Minimum dispersal of selected YSH tephras based on new correlations with distal sites. Color circles show locations of the analyzed distal tephra samples. Ovals of matching colors show minimum dispersal areas for tephra units 56, 59, and 58 ("Lower yellow"). Findings of YSH tephras in the marine cores SO201-2-81 and SO201-2-77 are the first ever findings of Shiveluch tephra in the marine sediments, which allow us to estimate the minimum dispersal of Holocene Shiveluch tephra at 560-580 km. Inset shows the location of Attu Island, where tephra samples attributed by Kyle et al. (2011) to Shiveluch likely come from another source (see text for discussion)

Fig. 14 Results of comparison of glass compositions in distal tephras with the proximal YSH high-Si glasses. a - "Lower yellow" (LY) tephra was used as a marker in the Eastern Kamchatka but its source was not known because its composition did not match then known YSH ones (Kyle et al. 2011). Comparison of LY glass to our proximal data shows that it matches early Holocene YSH tephras. b - $\mathrm{SH}_{5}$ tephra is one of the markers from YSH dispersed to the south of the volcano earlier dated at $\sim 2550{ }^{14} \mathrm{C}$ yrs based on erroneous correlation to unit 24 (Ponomareva et al. 2007). Comparison of the glass data for distal and proximal tephras have allowed us to correlate the distal tephra to YSH unit 21 dated at $\sim 1850$ cal BP. c - glass compositions of tephras found in the Bering Sea cores SO201-2-77KL and -81KL in association with the PL2 marker tephra ( 10.2 ka; Plosky eruptive center) suggest their correlation to proximal early Holocene YSH units 56 and 59. d - glasses from the three tephras found on Attu Island and attributed to Shiveluch (Kyle et 
al. 2011) form a single group and have lower $\mathrm{K}_{2} \mathrm{O}$ contents than the majority of the YSH glasses

1173

1174 Online Resource 1 Schematic summary section through Late Glacial - Holocene Shiveluch 1175 pyroclastic sequence

1176 Online Resource 2 OxCal code used for calibrating the sequence of radiocarbon dates obtained 1177 for the Shiveluch pyroclastic deposits

1178 Online Resource 3 Calibrated ages of the Shiveluch tephra units and marker tephra layers from 1179 other volcanoes

1180 Online Resource 4 Compilation of data on Shiveluch glass compositions and statistical tools for 1181 their comparison

1182 Online Resource 5 Electron microprobe analyses of glass from distal Shiveluch tephras 1183 mentioned in the paper

1184 Online Resource 6 Chemical analyses of bulk tephra used in this paper 


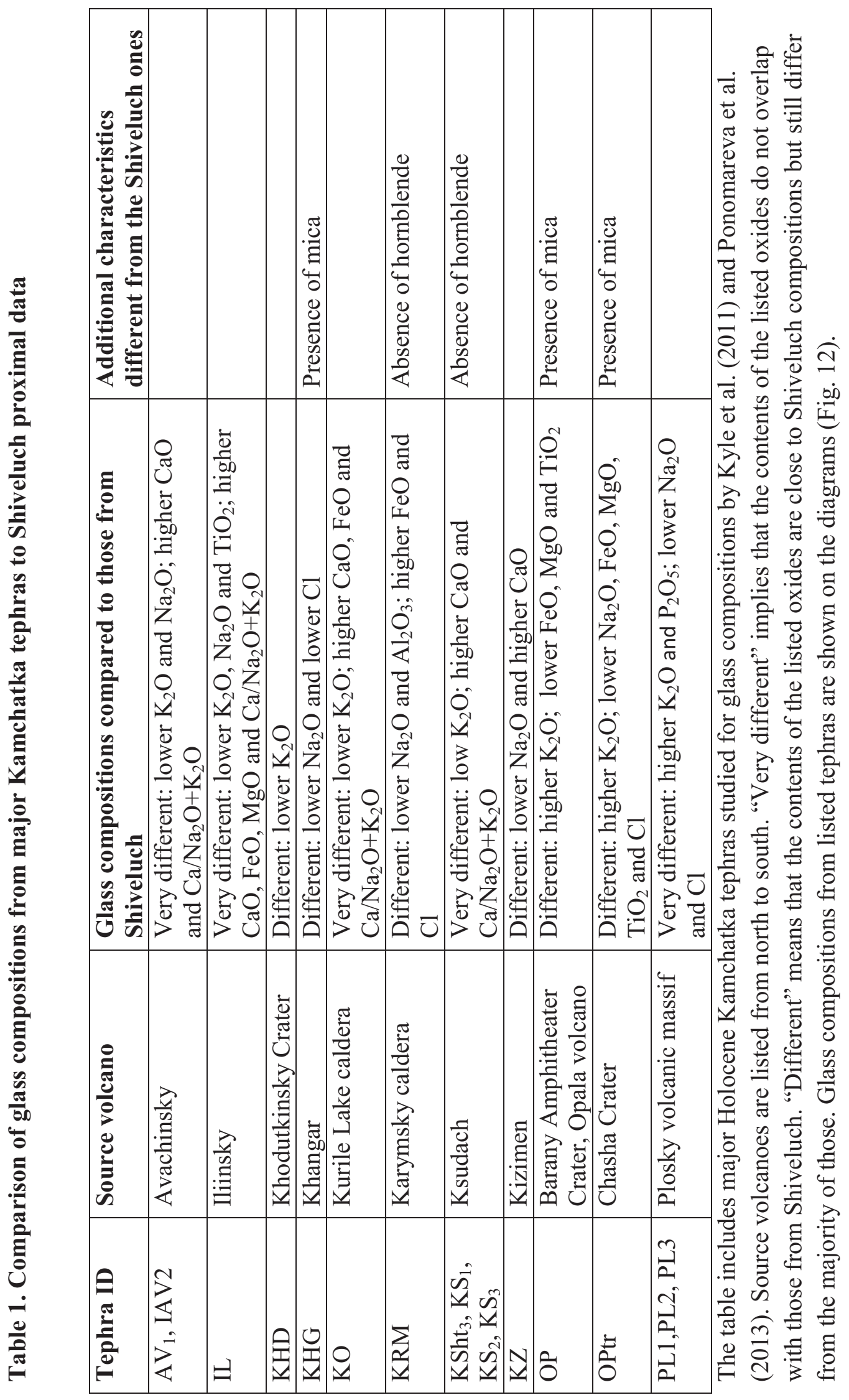




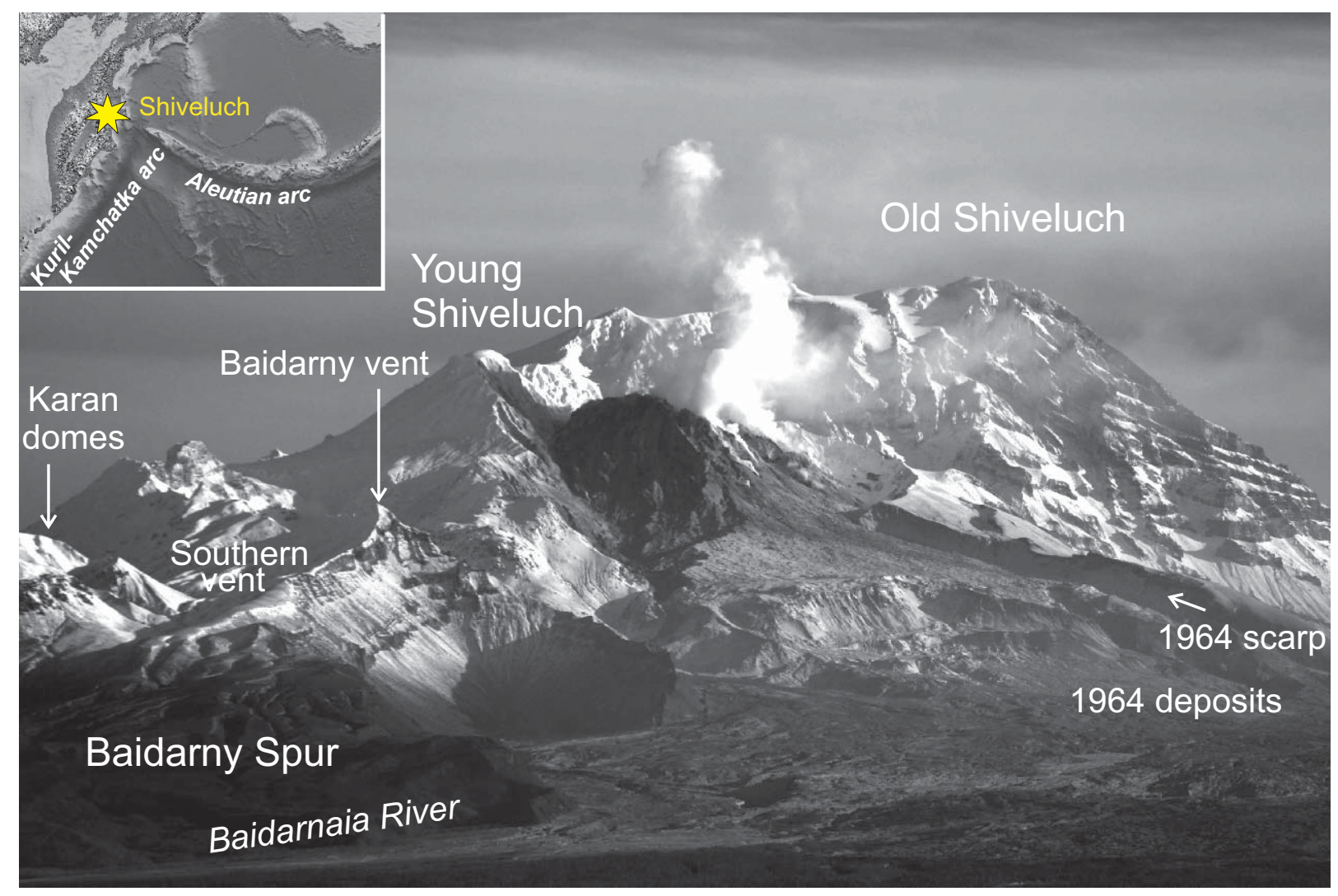

Fig. 1 


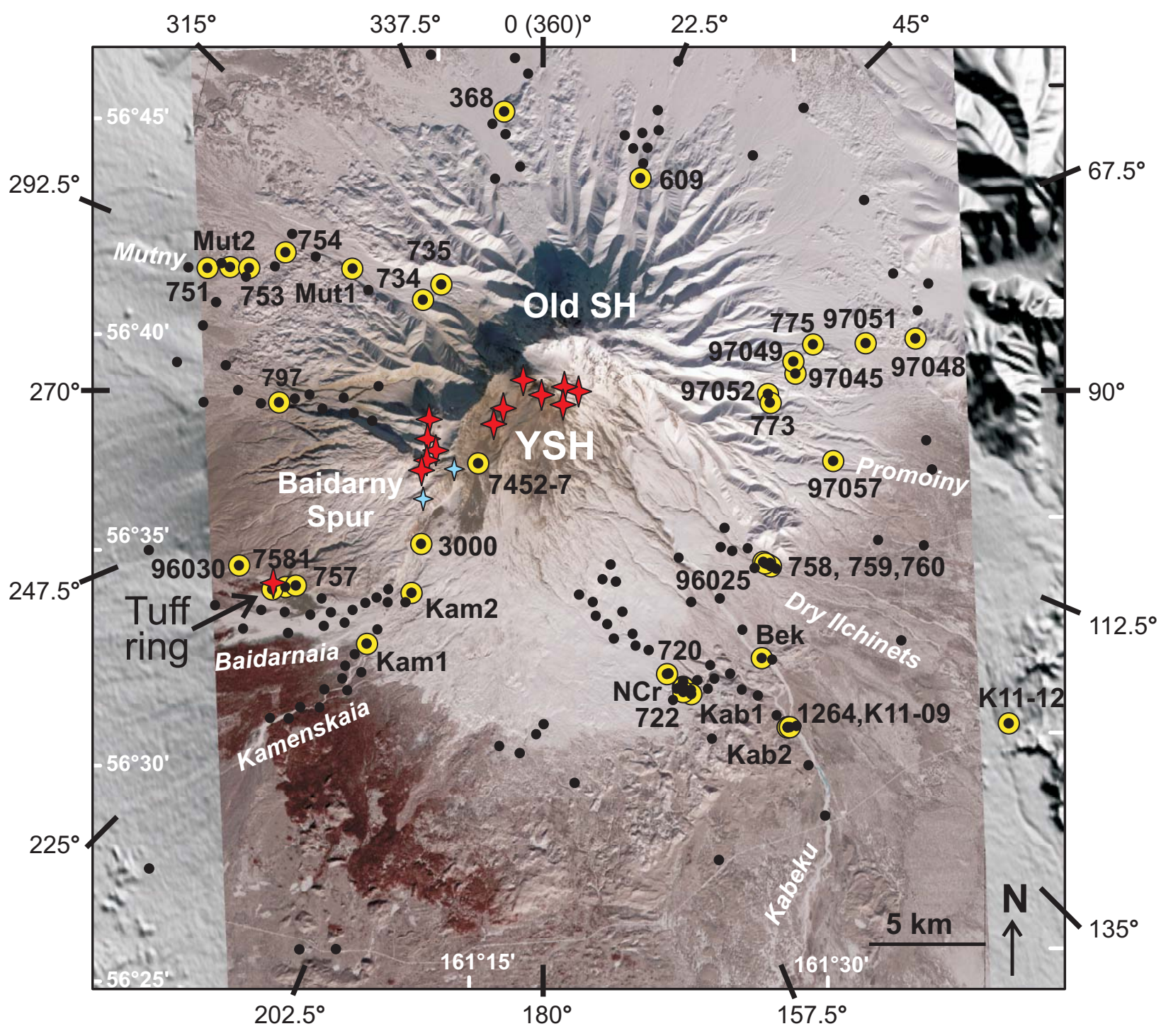

Fig. 2 

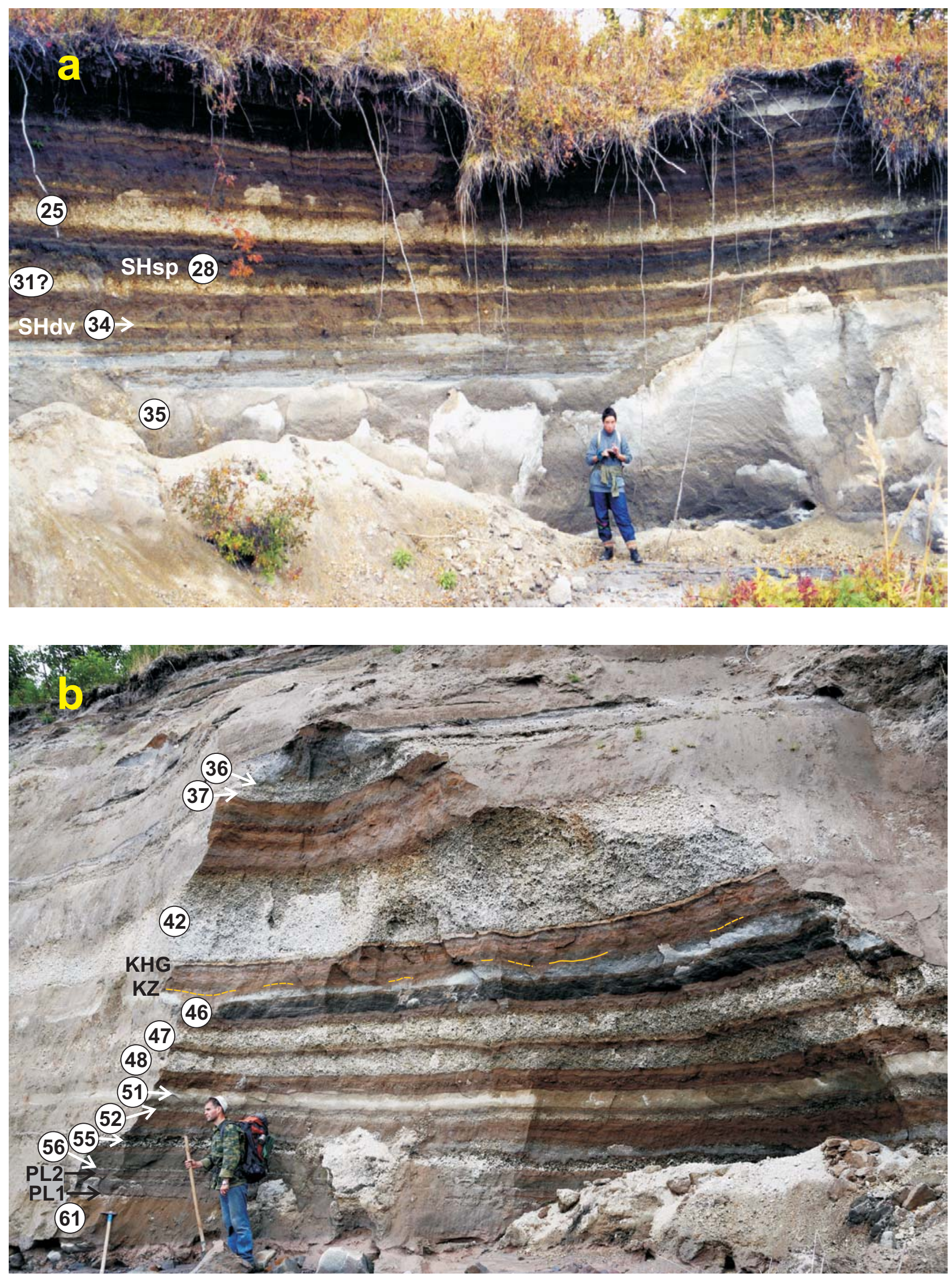

Fig. 3 


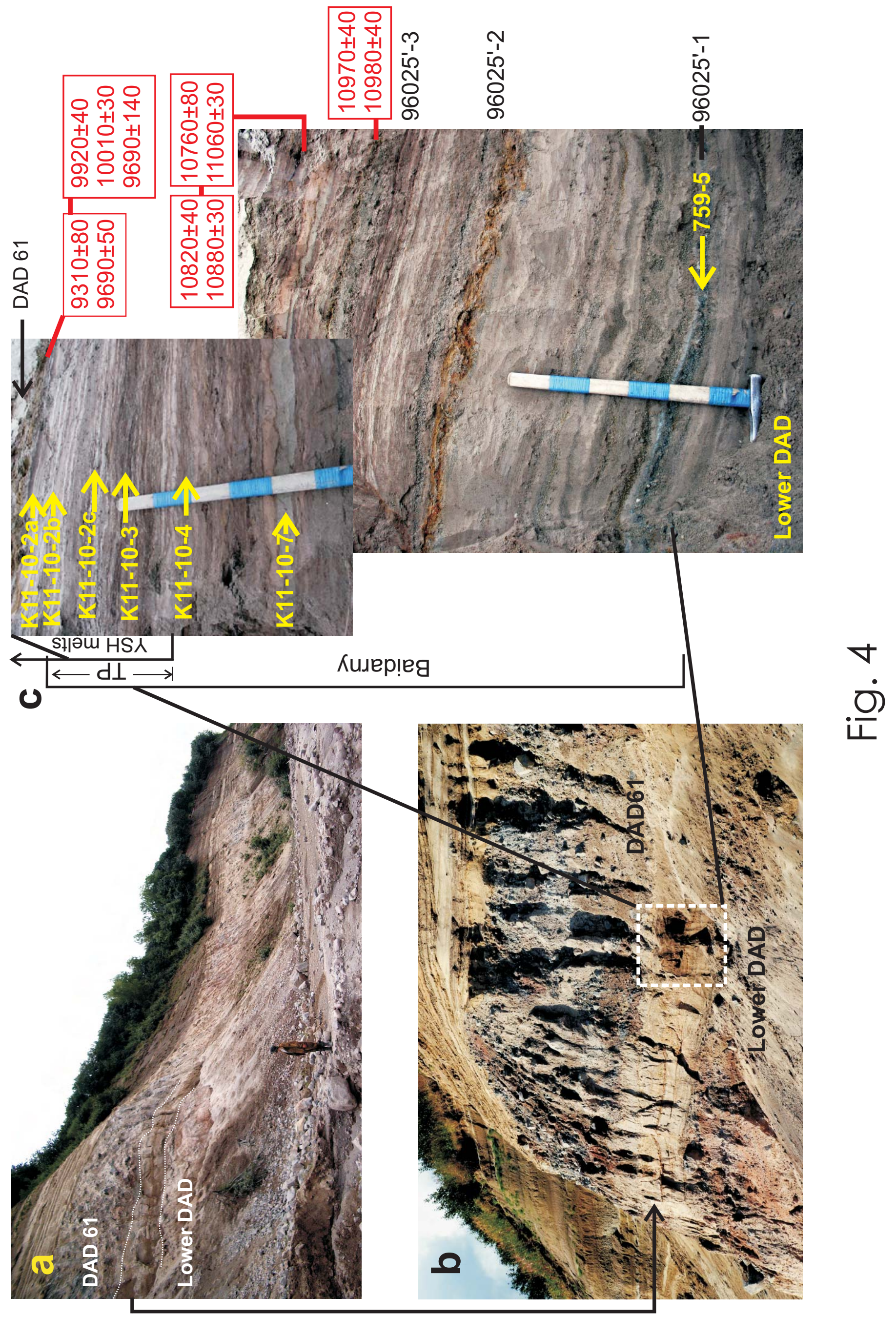




\section{Sl|əm HS人

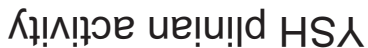

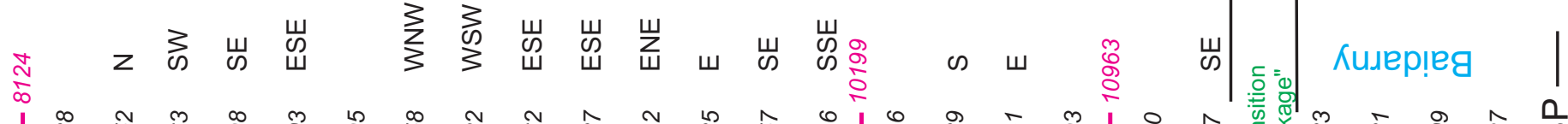

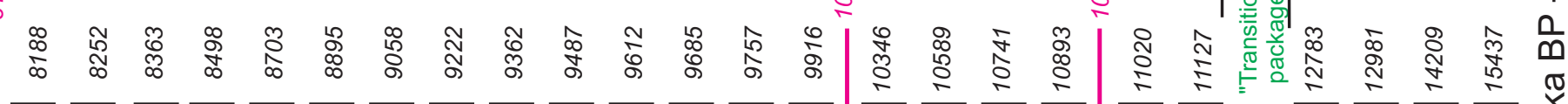

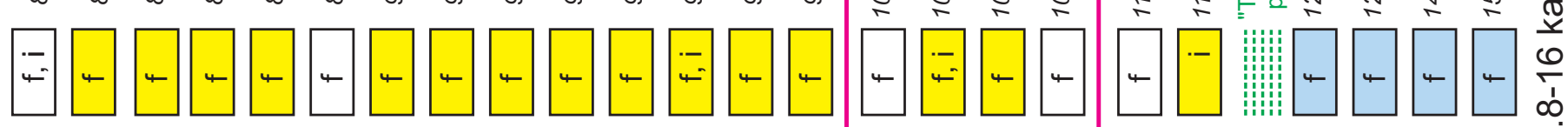

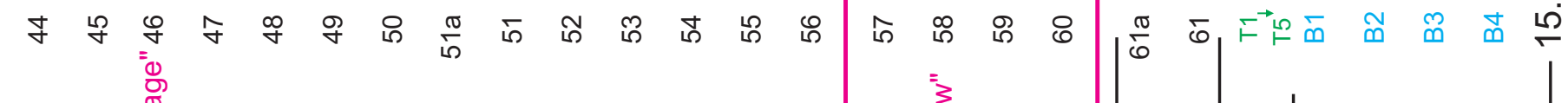
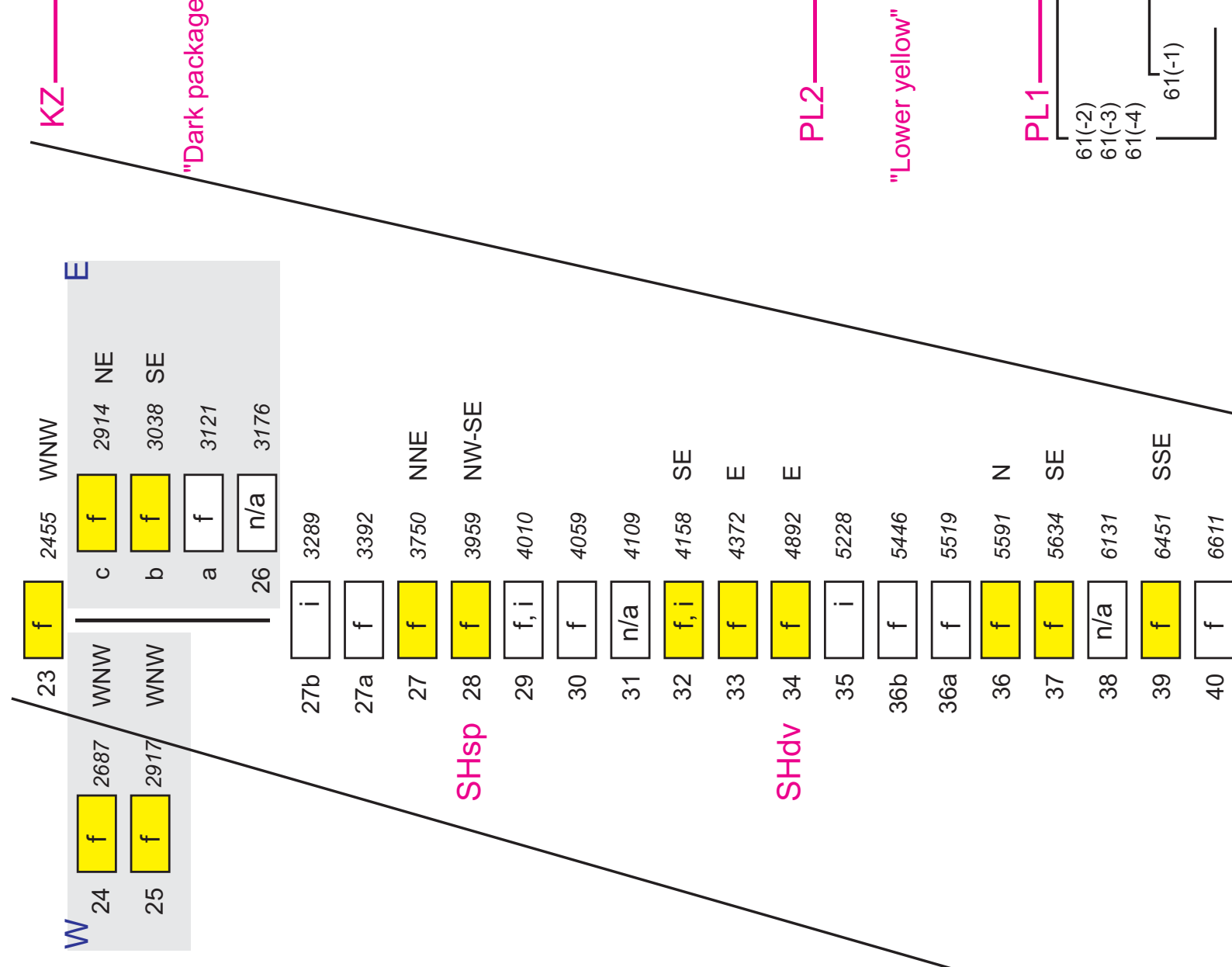

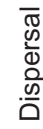

崫 ш $z$ 虰
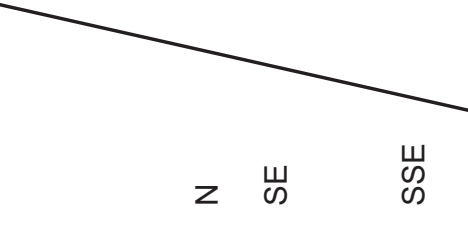


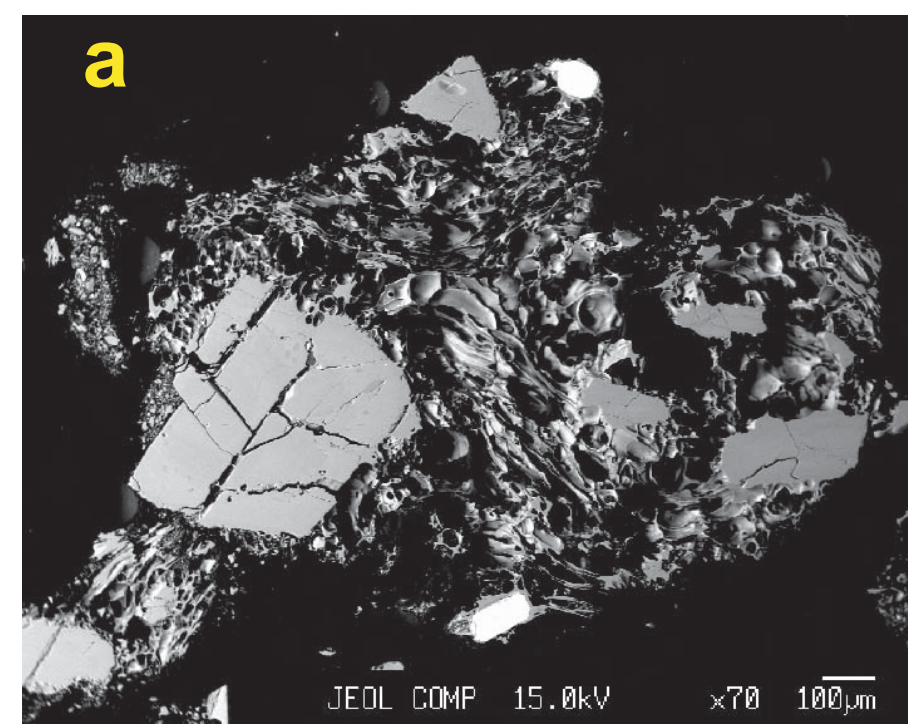

YSH unit 4, SH1, 757-1

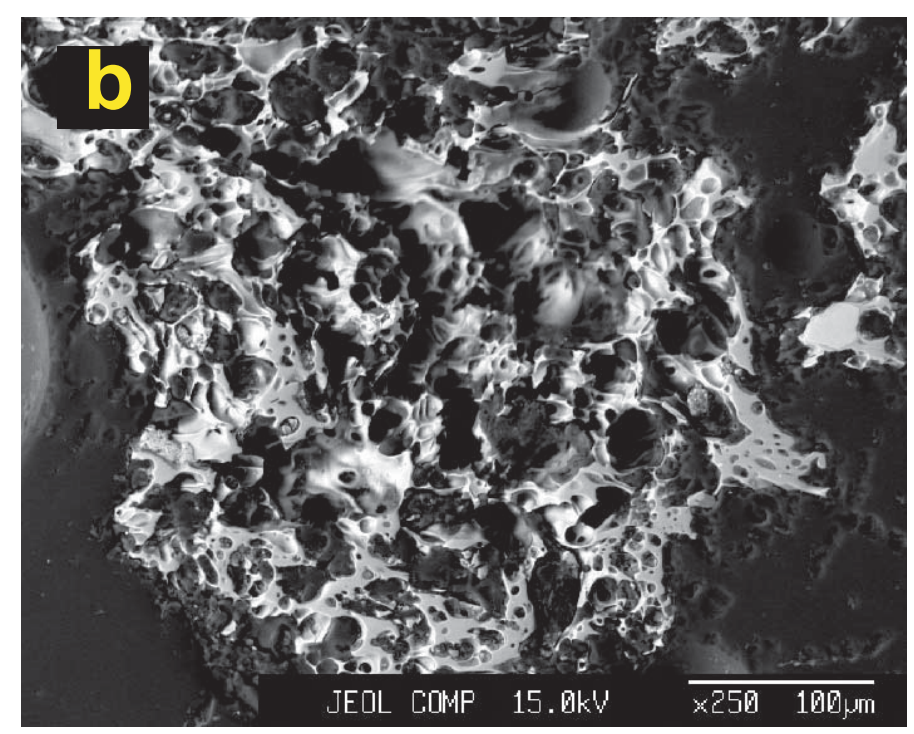

YSH unit b, SH2800, 775-8

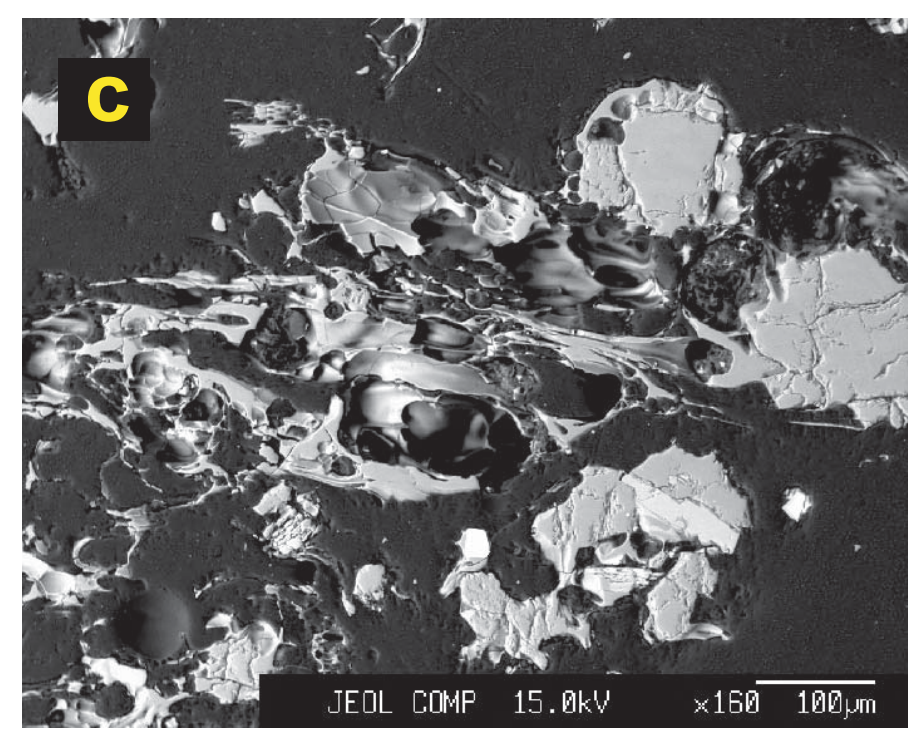

YSH, 775-25

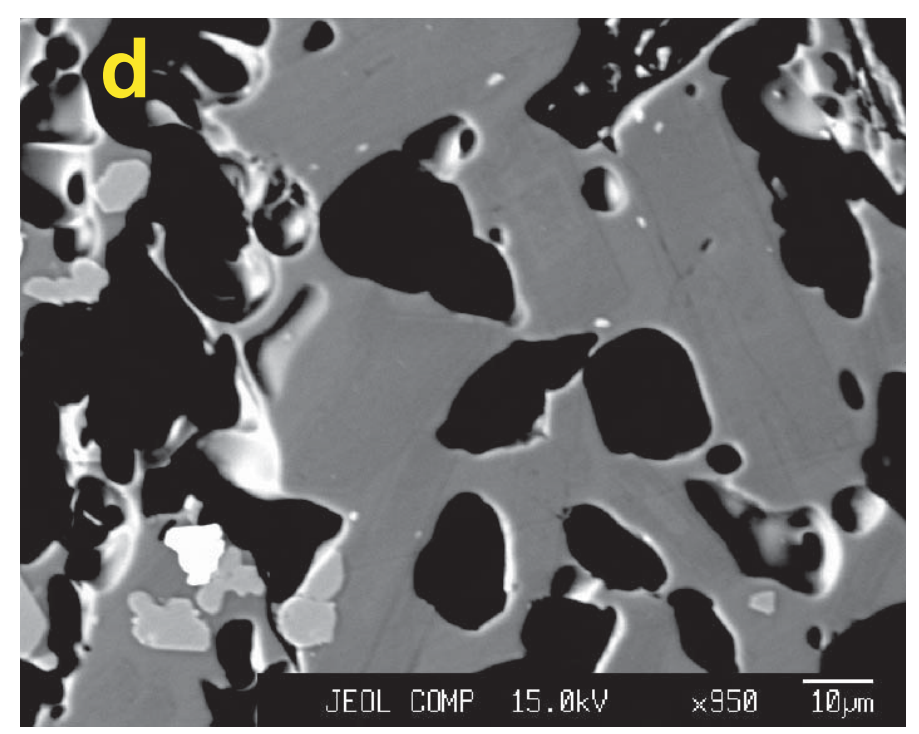

YSH unit 28, SHsp, 757-20

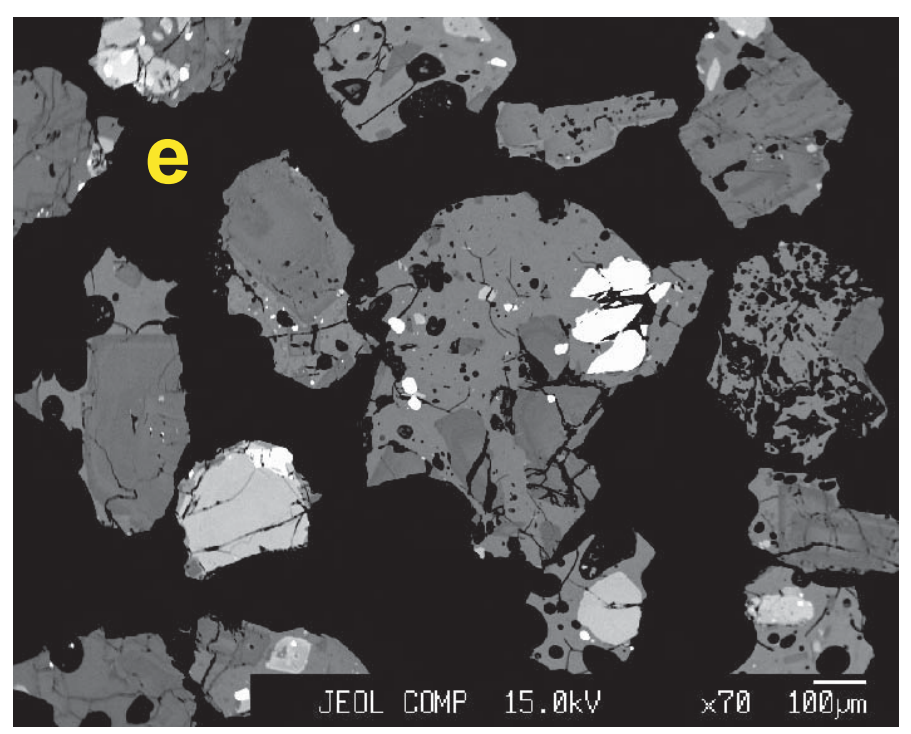

YSH unit 46, Dark package, K01-17

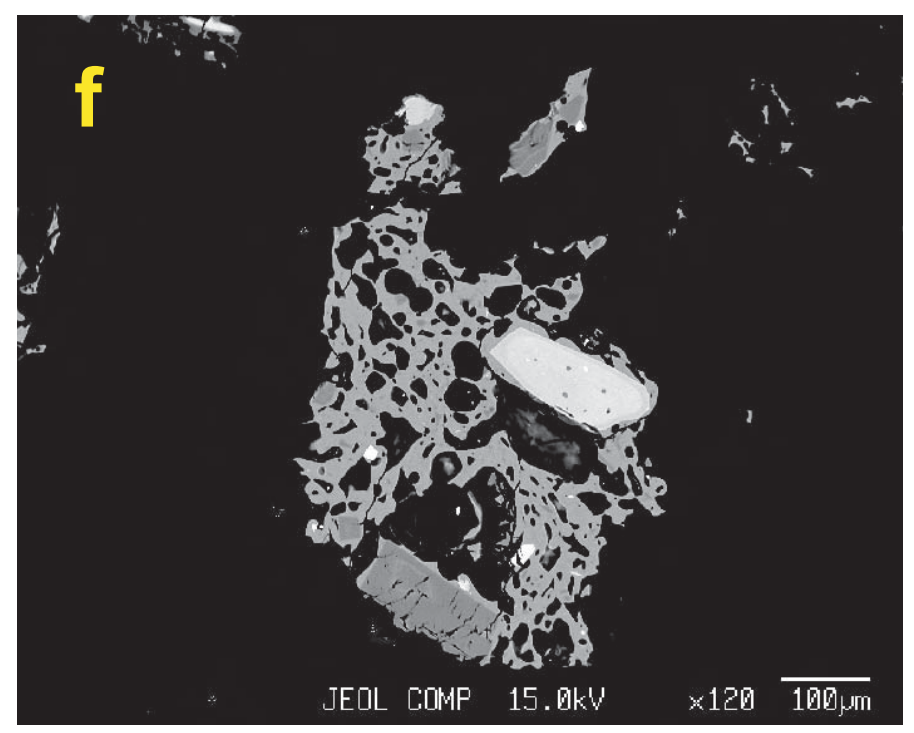

Baidarny, 97057-3 


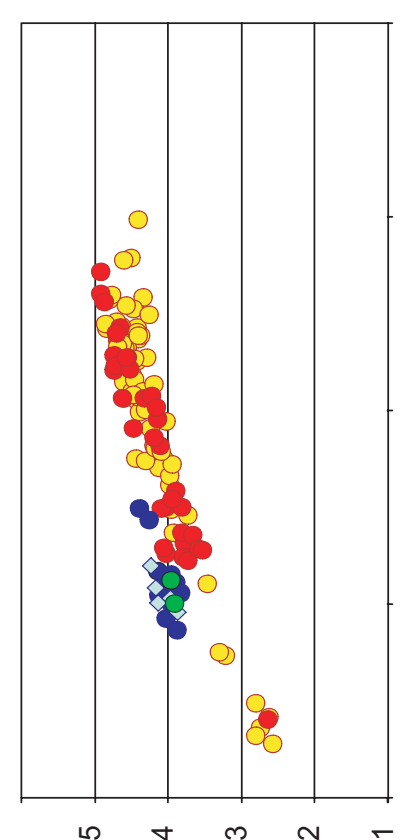

(\%"सM) OZeN

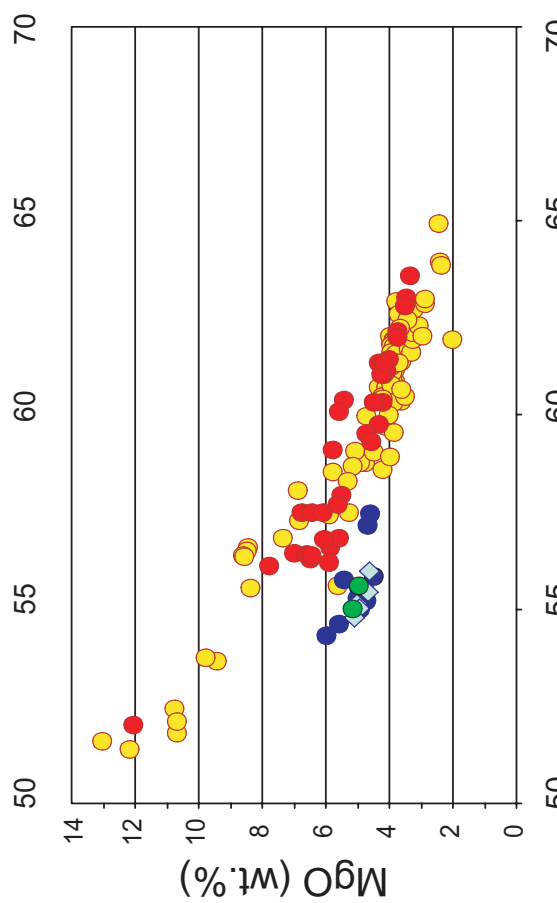

운

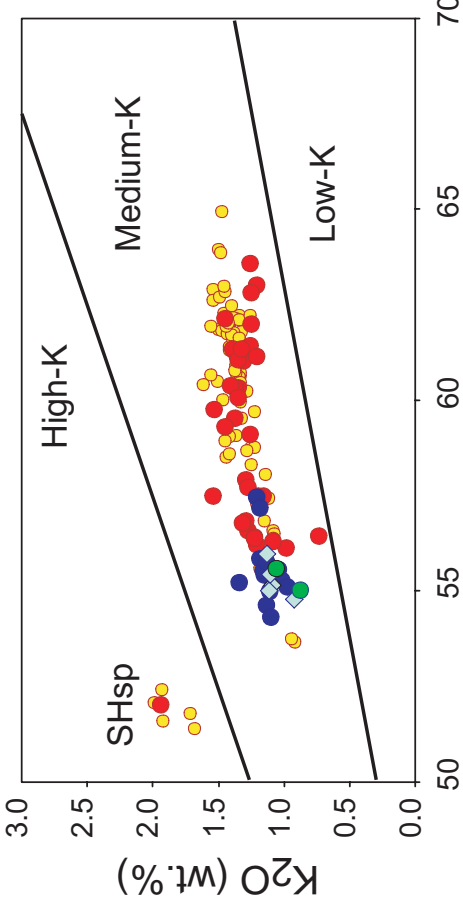

(\%'†M) OZ्र

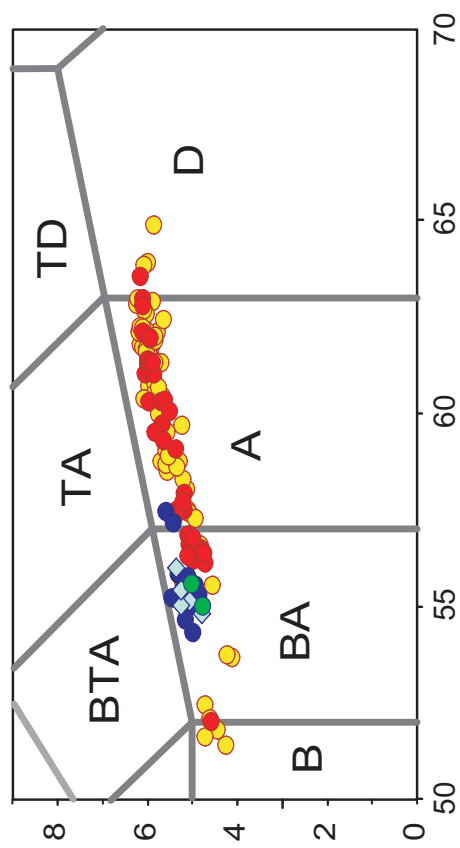

(\%'।M) OZYYY+OZeN
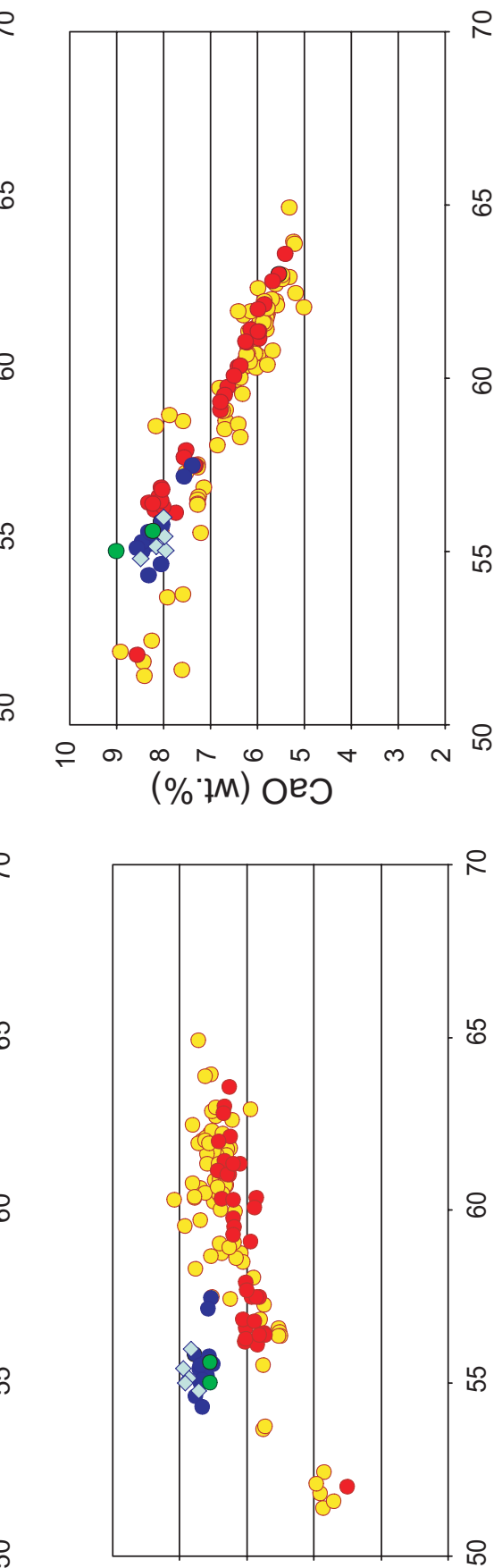

교유

$(\% \cdot \eta M) \varepsilon_{O} Z_{\mid V}$

운

ㅇ
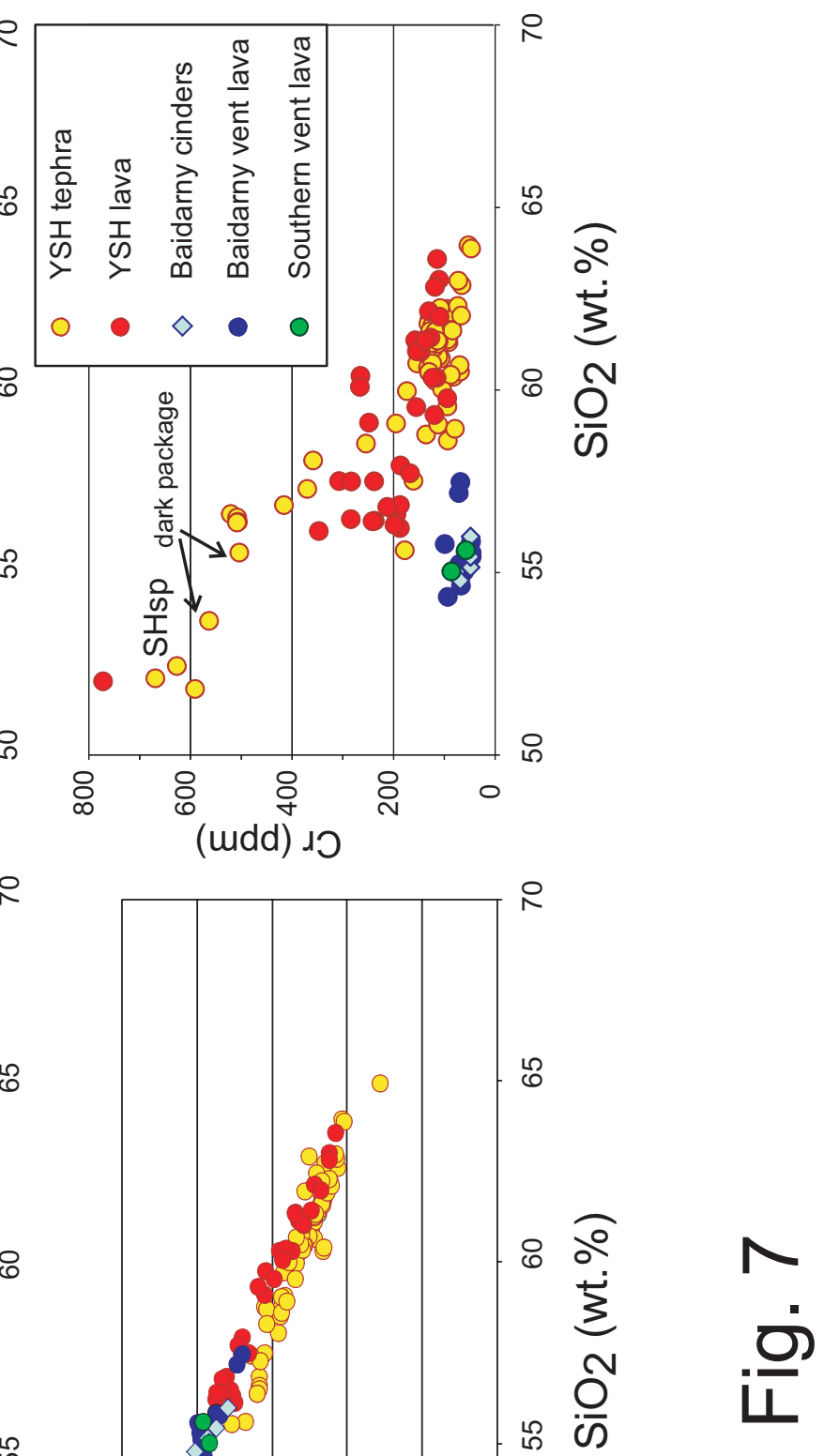
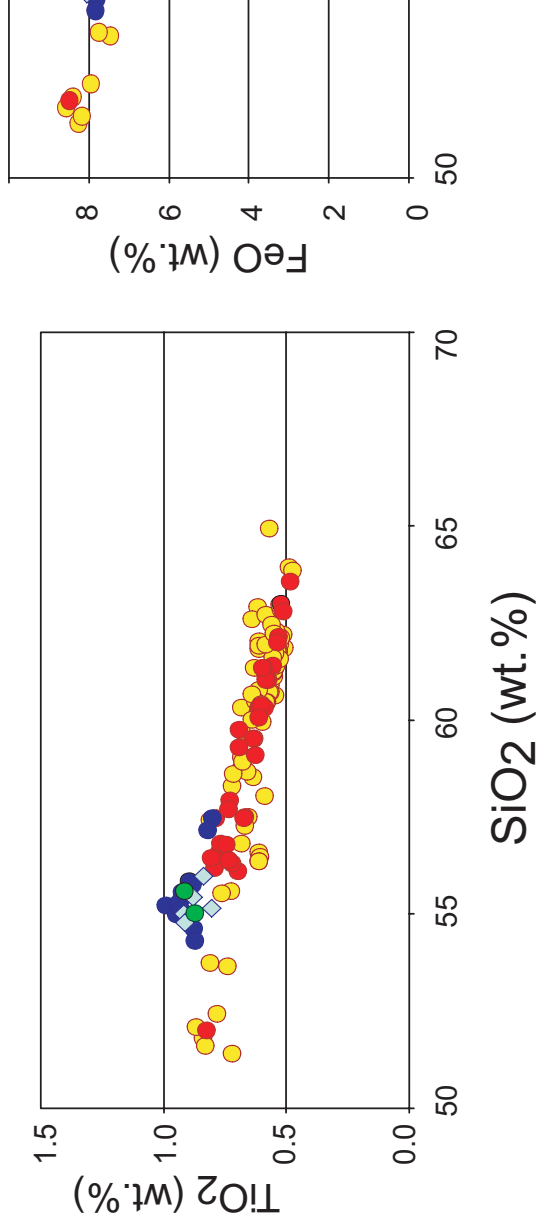


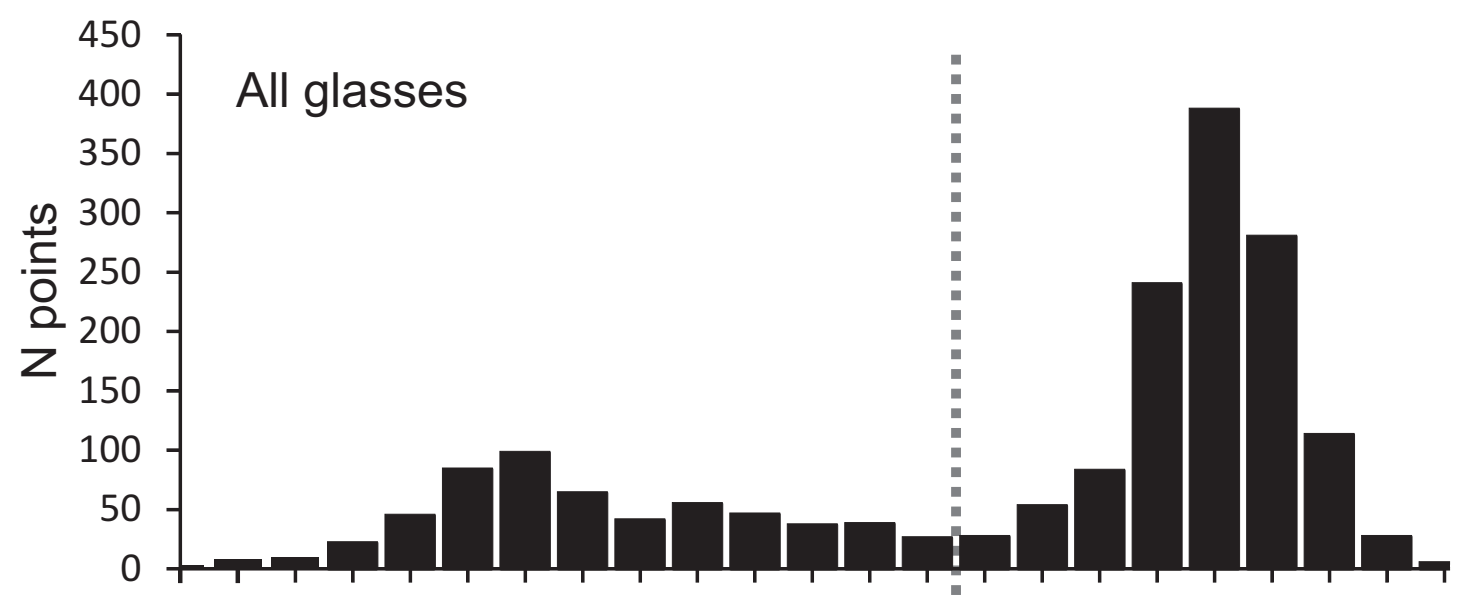

$5859606162636465666768697071=727374757677787980$

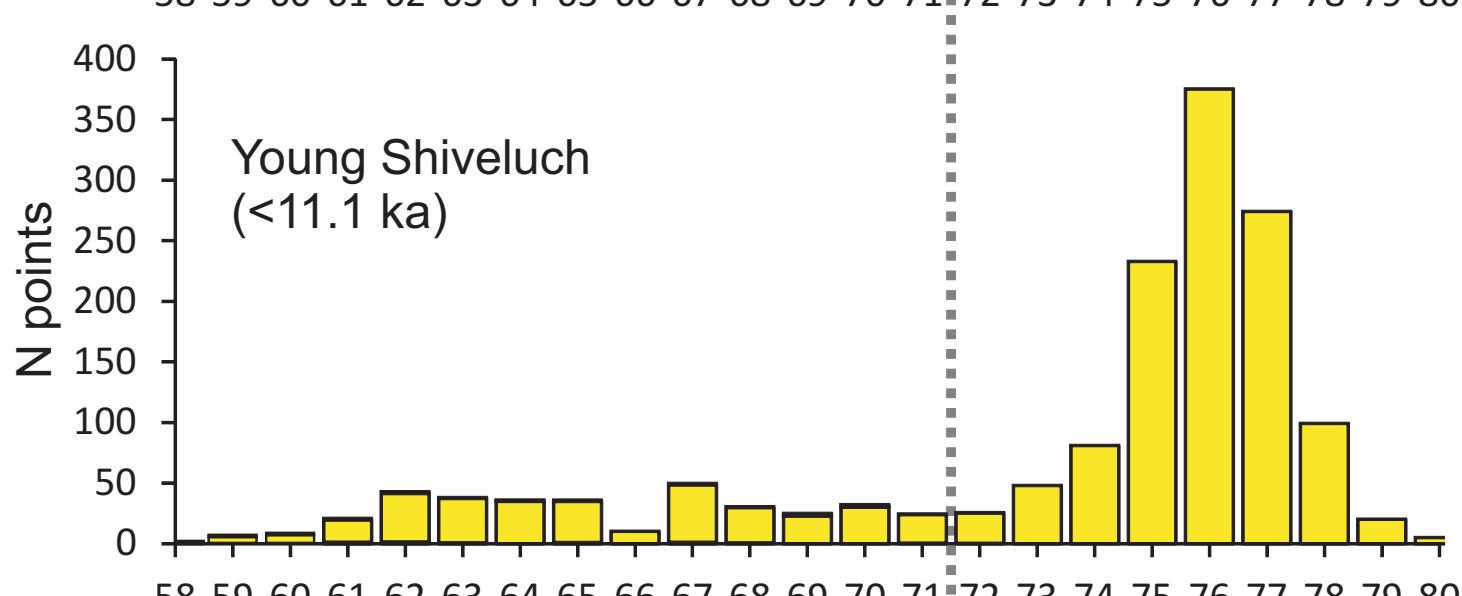

$5859606162636465666768697071=727374757677787980$

Transitional

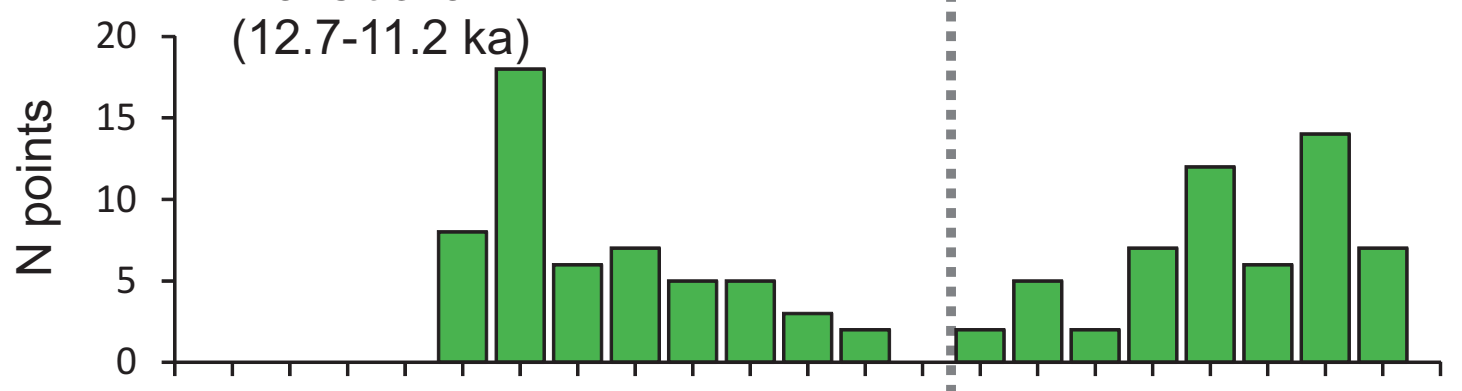

$5859606162636465666768697071=727374757677787980$

Baidarny

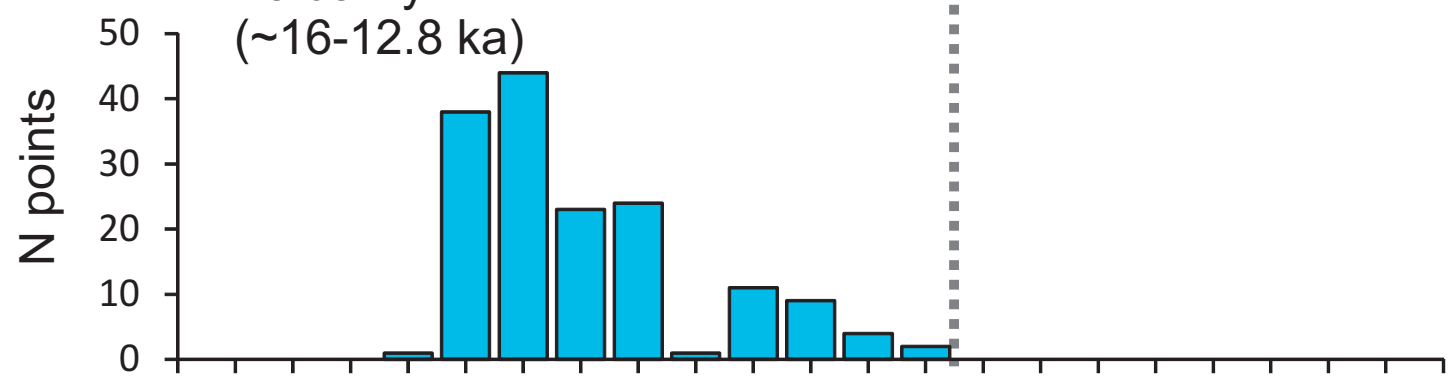

5859606162636465666768697071727374757677787980

$\mathrm{SiO}_{2}$ in glass $(\mathrm{wt} \%)$

Fig. 8 

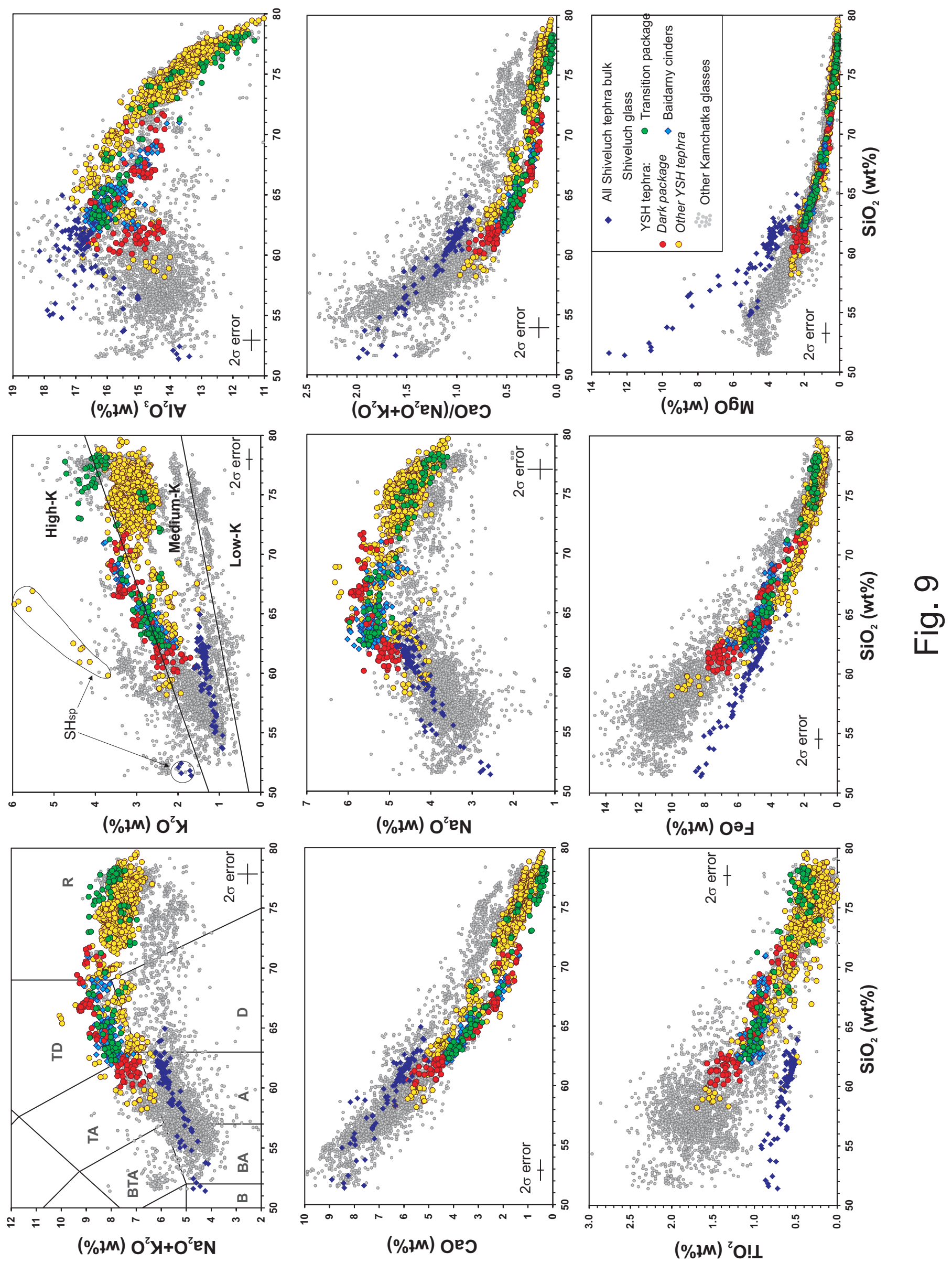

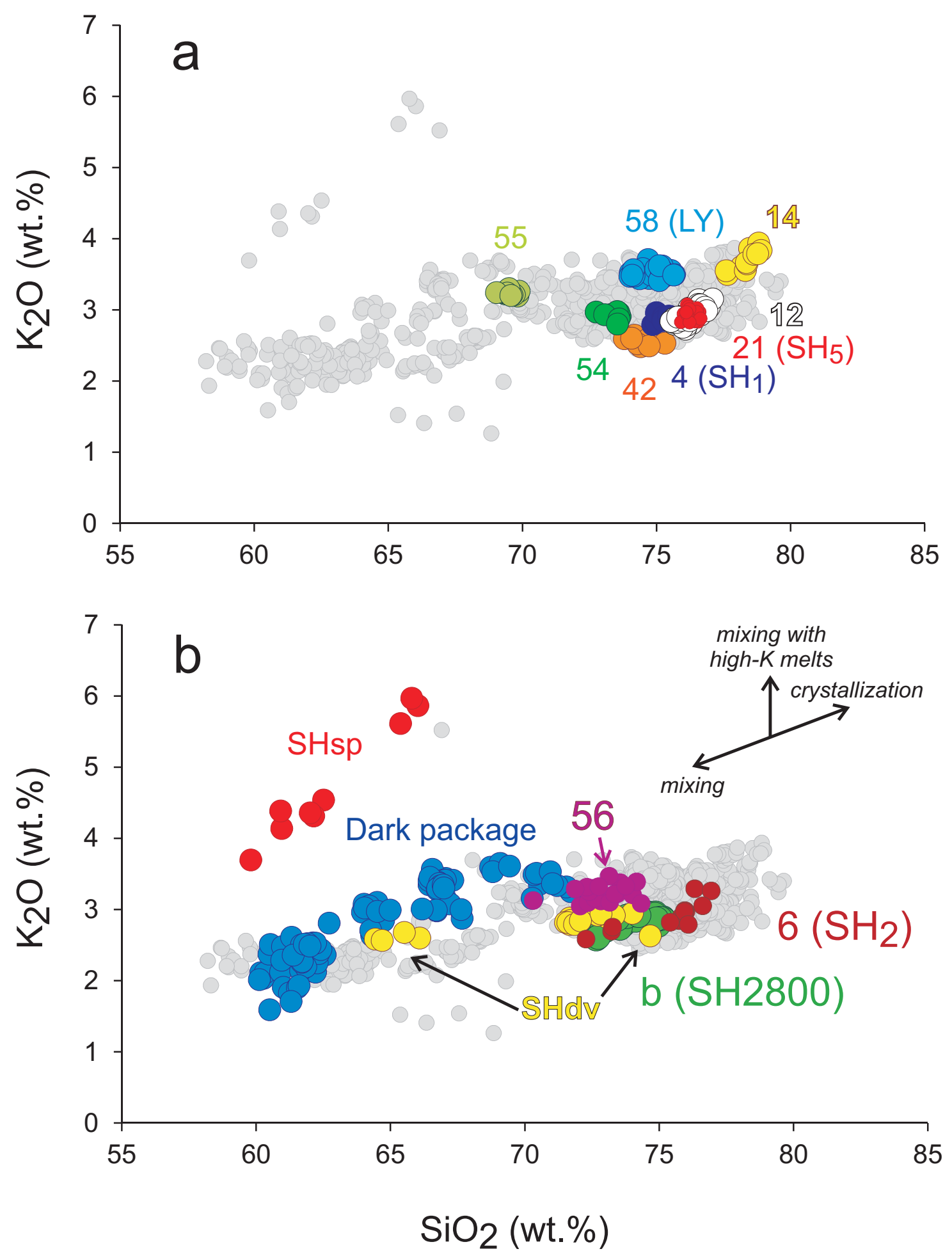

Fig.10 


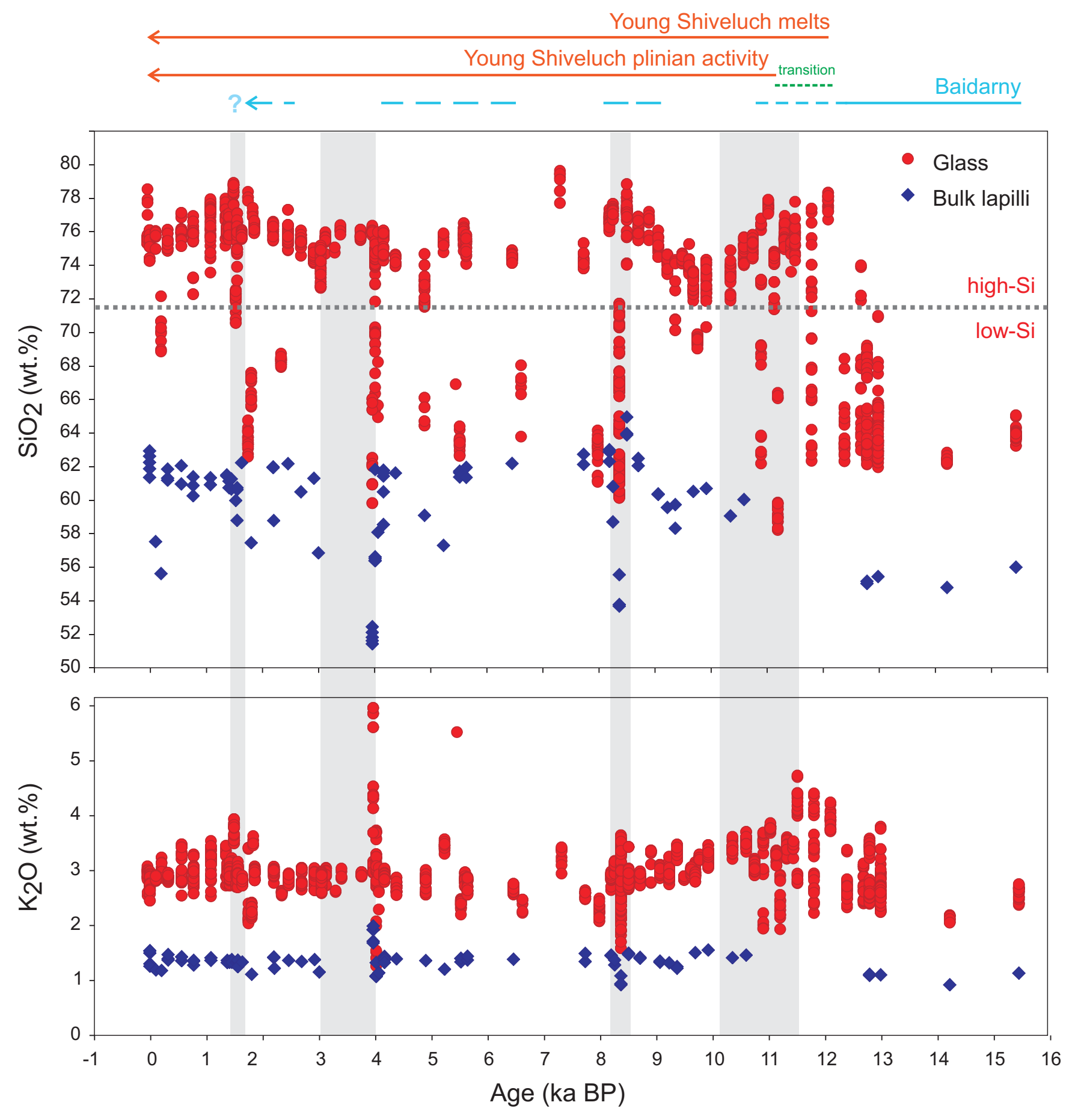

Fig. 11 


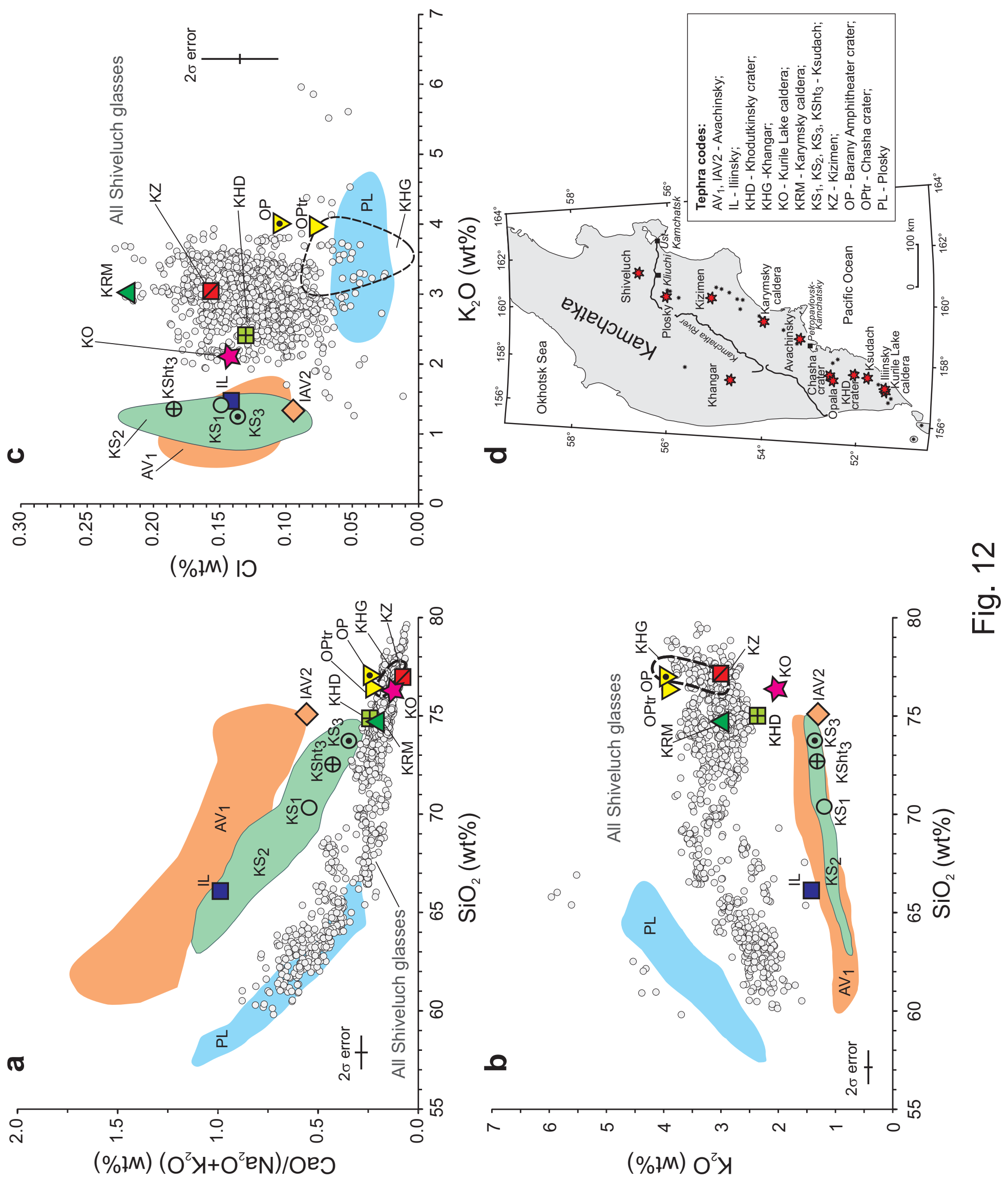




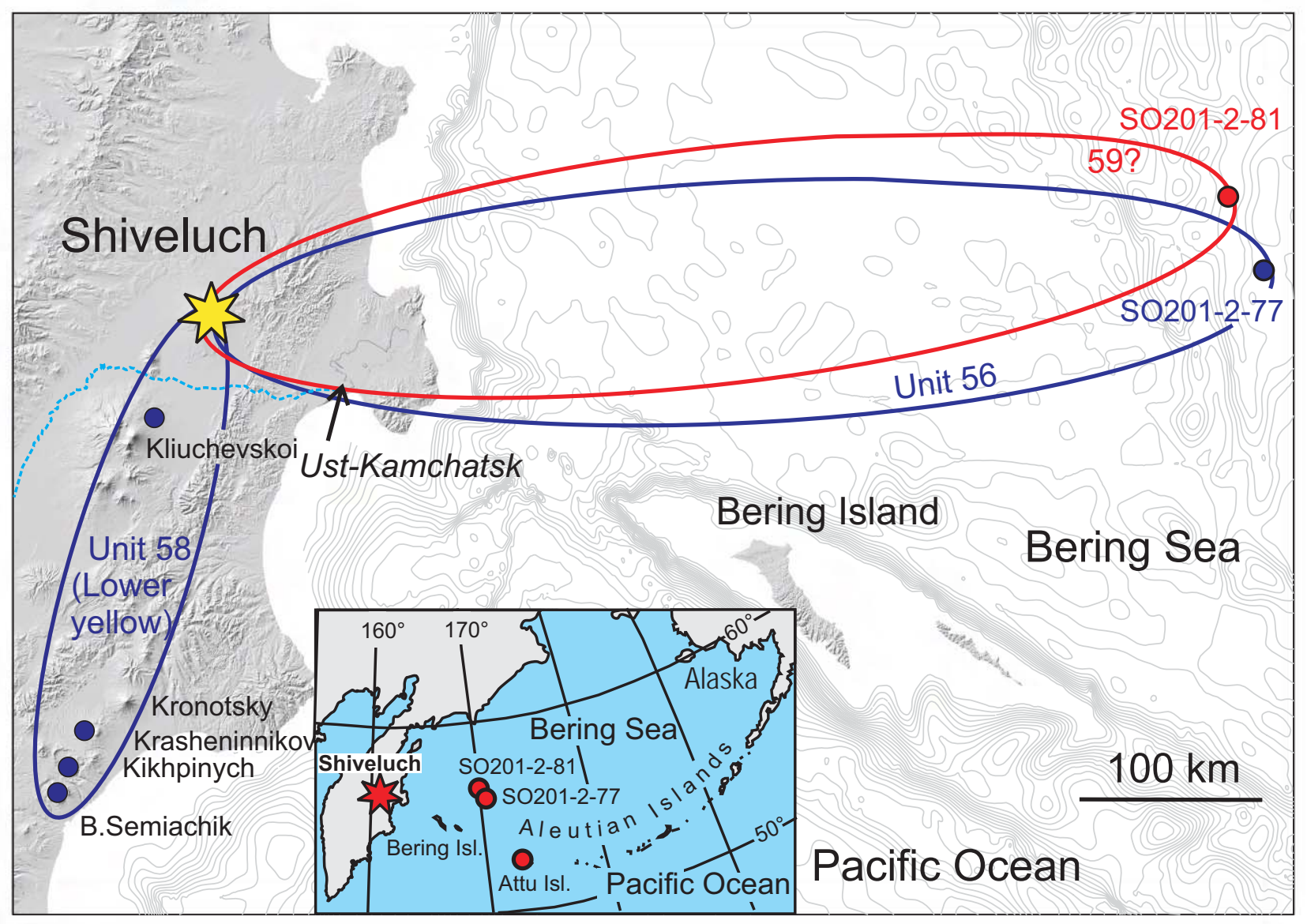

Fig. 13 


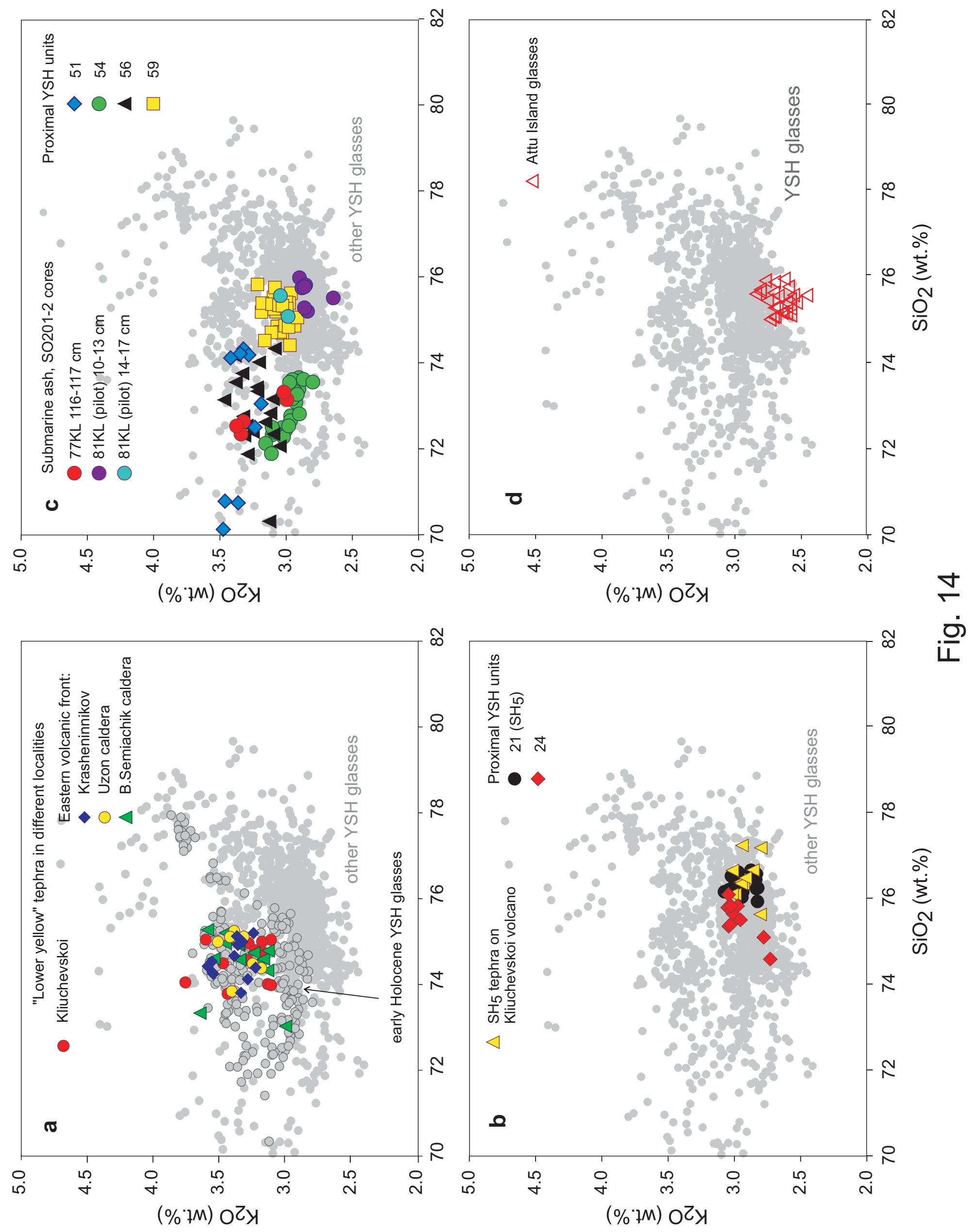

